\section{MIDDLE BRONZE AGE STRUCTURES (AREAS B AND C)}

Areas B and C were located on top of a knoll and measured approximately $300 \mathrm{~m}$ north-west to south-east and $100 \mathrm{~m}$ north-east to south-west. The results from these two excavation areas (Illus 2 and Illus 5) are presented together as they were adjacent and the structures within them contemporaneous. The dates suggest Middle Bronze Age (MBA) occupation. The areas contained six structures in total: Structures 2B, 4B, 5B, 6B, 7B and 3C (Illus 5). Five of these post-built circular structures had a ring ditch component.

The interpretation of the group of features within Area $\mathrm{C}$ was made difficult because of truncation, particularly on its eastern side due to erosion downslope. However, within the centre of this cluster of features were architectural components recognisable as elements of a circular structure: these are ring grooves, a post ring, ring ditch and possible hearth.

The main structures in Area B will be described from south-west to north-east.

\subsection{Structure 4B}

\subsubsection{General summary}

This feature complex measured $10 \mathrm{~m}$ by $12 \mathrm{~m}$ overall (Illus 6). Its extent was defined by a ring groove on the north and east, which contained four post holes and the outer edge of a ring ditch and an arc of posts on the south and west. This post ring continued along the inside of the ring groove in the north and east. The post ring encircled the penannular ring ditch, which had pits cut into its base. An arc of four pits was present on the inner lip of the ring ditch. There were internal features including a possible firepit. All features were sealed beneath a charcoalrich deposit.
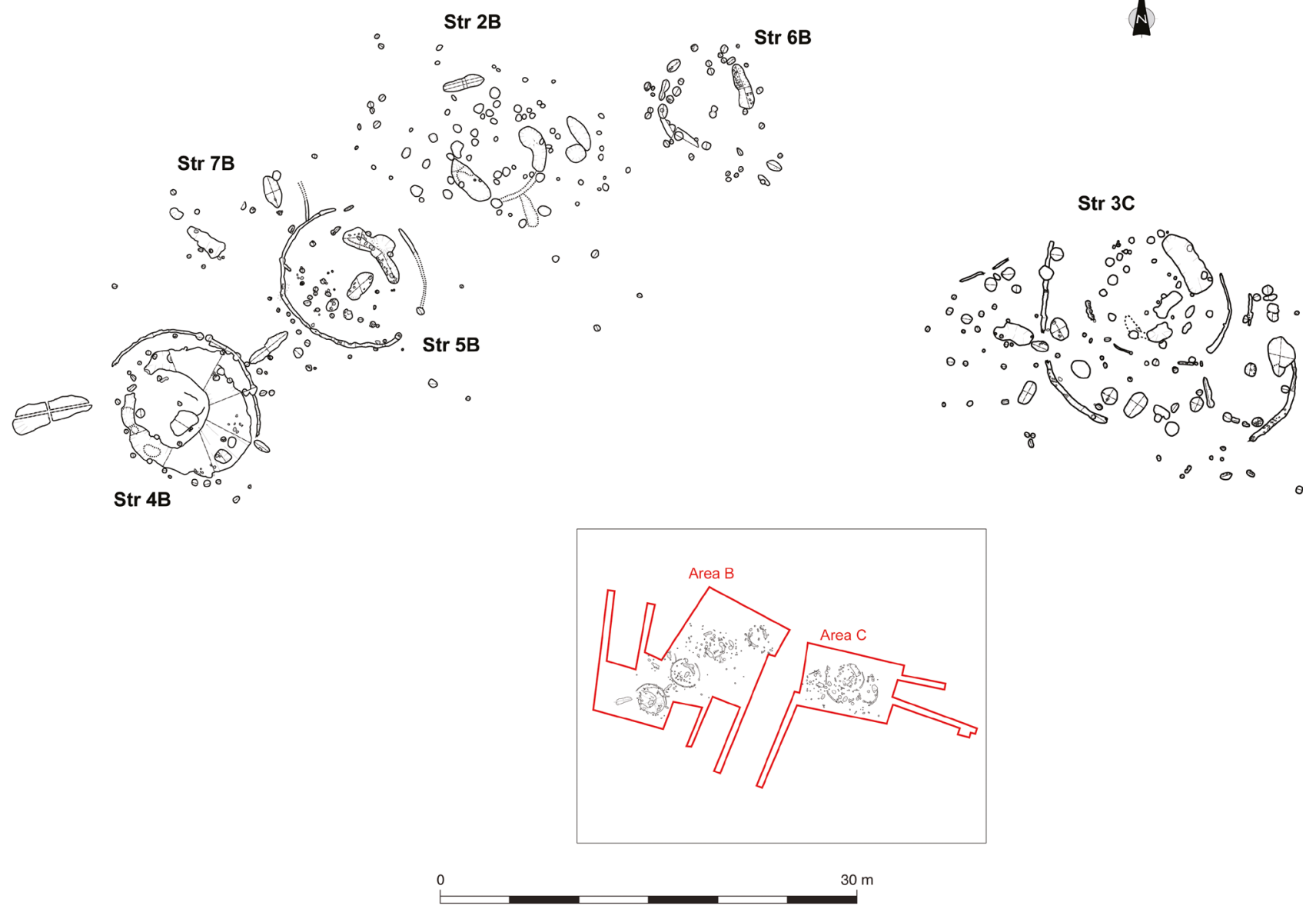

Illus 5 Areas B and C site plan 


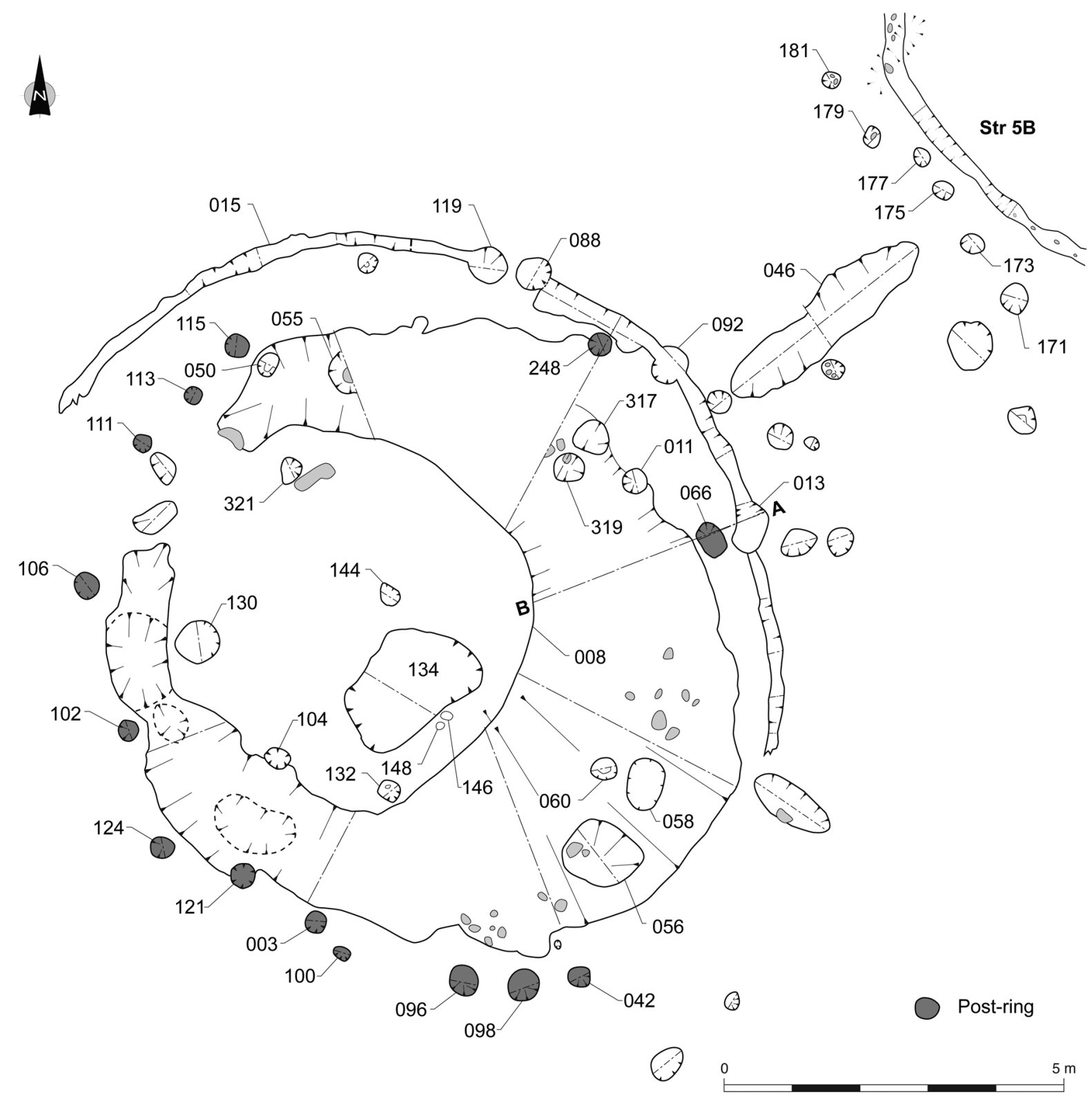

\section{Illus 6 Plan of Structure 4B, Area B}

\subsubsection{Description}

The ring groove $(015)$ measured $c 0.3 \mathrm{~m}$ wide by $0.2 \mathrm{~m}$ deep and was filled with firm dark brown/ black silt. Within the ring groove were four post holes (119, 088, 092 and 013), all of similar form, which ranged in size between $0.3-0.4 \mathrm{~m}$ in diameter by $0.07-0.1 \mathrm{~m}$ deep. There was no stratigraphic relationship between the ring groove and the rest of the structure's features. The ring groove was not concentric to the penannular ring ditch (008), being $0.5 \mathrm{~m}$ from the ring ditch at its southern tip and $2 \mathrm{~m}$ away at its north-western tip. However, this could be due to truncation of the site or other wear patterns.

A ring of 14 post holes (clockwise from the south: 042, 098, 096, 100, 003, 121, 124, 102, 106, 111, $113,115,248$ and 066) encircled the penannular ring ditch (008). They were similar in form and ranged in size from $0.3 \mathrm{~m}$ diameter by $0.1 \mathrm{~m}$ deep to $0.3 \mathrm{~m}$ diameter by $0.28 \mathrm{~m}$ deep. Post Hole $121 \mathrm{cut}$ the ring ditch on its south-east side. This post ring was erratic and not concentric with the ring ditch or ring groove. The post holes were not evenly spaced, perhaps due to truncation.

Penannular Ring Ditch 008 measured up to $2 \mathrm{~m}$ wide by $0.4 \mathrm{~m}$ deep. It was filled with two deposits 


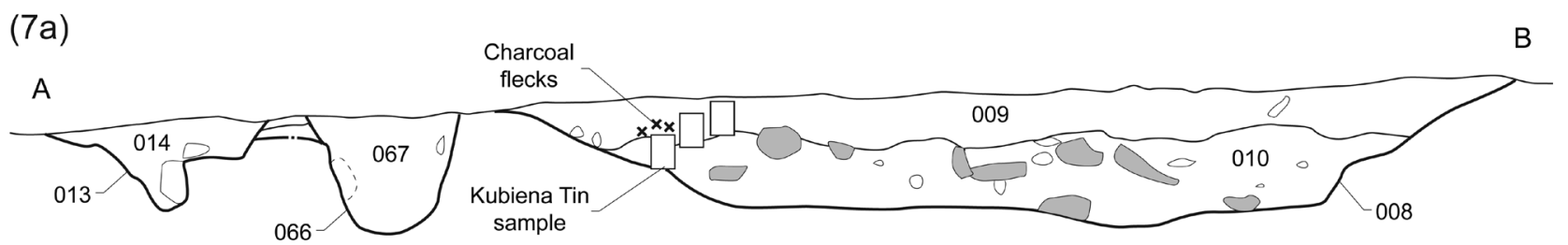

(7b)

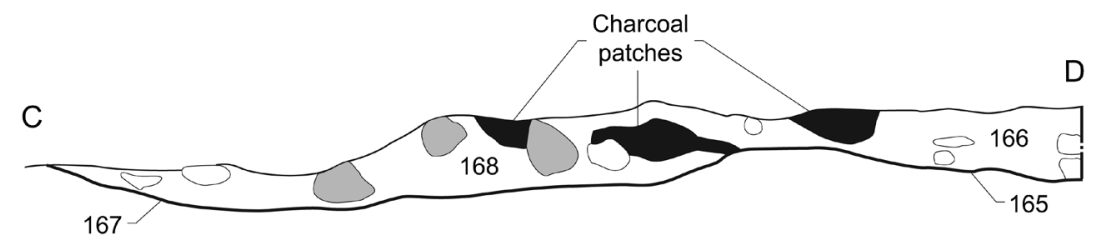

(7c)
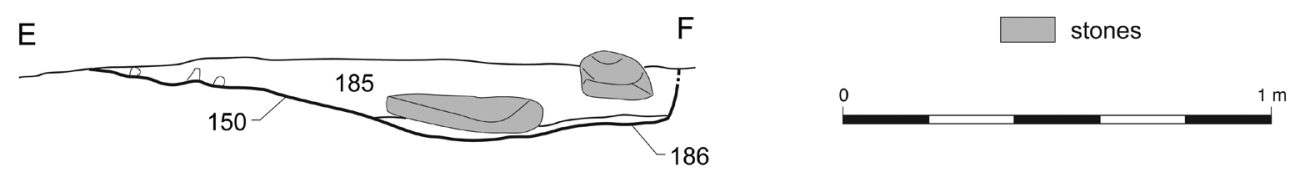

Illus 7 Selected sections of Structures 4B and 5B, Area B

(Illus 7a): the lower was dark brown silt (010) that contained $c 40 \%$ stones $0.2-0.3 \mathrm{~m}$ in size, and the upper fill was the black charcoal-rich material (009), which also sealed all the other features of this structure. Soil micromorphological analysis carried out on the fills of the ring ditch (Ellis, Section 4.9.4 below) suggests that the fill (009) contained a high proportion of turf and herbaceous ash. This fill also contained the majority of the pottery recovered from this structure complex. The terminals of the ring ditch were orientated to the north-west.

Within the ring ditch base were eight pits (050, $055,317,319,011,058,060$ and 056) that ranged in size from $0.4 \mathrm{~m}$ by $0.3 \mathrm{~m}$ by $0.11 \mathrm{~m}$ deep to $1.1 \mathrm{~m}$ by $0.96 \mathrm{~m}$ by $0.09 \mathrm{~m}$ deep. These pits were cut into the subsoil within the base of the ring ditch and were sealed by the basal fill (010).

An arc of four pits (132, 104, 130 and 321) was recorded on the inner western edge of the ring ditch and ranged in size from $0.3 \mathrm{~m}$ diameter by $0.1 \mathrm{~m}$ deep to $0.45 \mathrm{~m}$ by $0.5 \mathrm{~m}$ by $0.3 \mathrm{~m}$ deep. The pits were filled with dark brown silt and the spacing between them was erratic. Four other internal features $(144,134,146,148)$ ranged in size from stake holes to a large pit. Although Pit 134 contained charcoal and small amounts of burnt bone within its fill, there was no evidence of burnt subsoil on the pit's edges or base. However, its near-central position in relation to the ring groove may lend support to the firepit interpretation, with the lack of in-situ burning being the result of the regular cleaning-out of the pit, including any burnt soil on the sides. The function of Stake Holes 148 and 146 on the south-east side of Pit 134 is undetermined but may be associated with the use of Pit 134 .

A line of six pits $(171,173,175,177,179,181)$ was recorded to the north-east of Structure $4 \mathrm{~B}$, running between Structures $4 \mathrm{~B}$ and $5 \mathrm{~B}$, and ranged in size from $0.27 \mathrm{~m}$ by $0.29 \mathrm{~m}$ by $0.07 \mathrm{~m}$ deep and $0.32 \mathrm{~m}$ by $0.35 \mathrm{~m}$ by $0.19 \mathrm{~m}$ deep. A linear pit (046) was also recorded between Structures $4 \mathrm{~B}$ and the line of pits, and measured $3.5 \mathrm{~m}$ by $0.85 \mathrm{~m}$ by $0.22 \mathrm{~m}$ deep.

\subsubsection{Interpretation and phasing}

It is likely that the features identified as Structure $4 \mathrm{~B}$ represent more than one structure. The ring groove (015) is not concentric with the post ring or the ring ditch, which would be expected if all these features were part of a single-phase structure. Post Hole 121 (a potential out-of-line post which 
may be a later insertion in the post ring) cut the ring ditch, thus suggesting that at least a later phase of the post ring post-dated the ring ditch, which must have already been filled by the time 121 was excavated.

The ring ditch appears to represent a structure with an internal diameter of $5 \mathrm{~m}$. Within the base of the ring ditch were pits cut into the natural subsoil. These may be the truncated remains of larger pits that pre-dated the construction of the ring ditch and therefore represent an earlier phase of building, or they may simply be shallow pits cut through the existing ring ditch floor. The pits were filled with loosely compacted grey or brown silts which differed from the firm dark brown to black silt of the primary fill of the ring ditch (010) which sealed them, suggesting that there was a delay between the two deposition events. However, their function remains undetermined.
The projection of the ring groove suggests that it was not contemporary with the post ring and that these features represent different phases of the structure.

The arc of four internal pits $(132,104,130$ and 321) may represent an inner post ring or, alternatively, these inner pits were perhaps foundations for an internal division within the structure, and did not function as load-bearing posts.

\subsection{Structure 5B}

\subsubsection{General summary}

This post-built structure measured $9.5 \mathrm{~m}$ by $11 \mathrm{~m}$ (Illus 8). The features making up the house were heavily truncated, which hindered the interpretation of the plan of the structure. The house was defined by a ring groove with an entrance orientated to the south-east. A partial ring of post holes was present

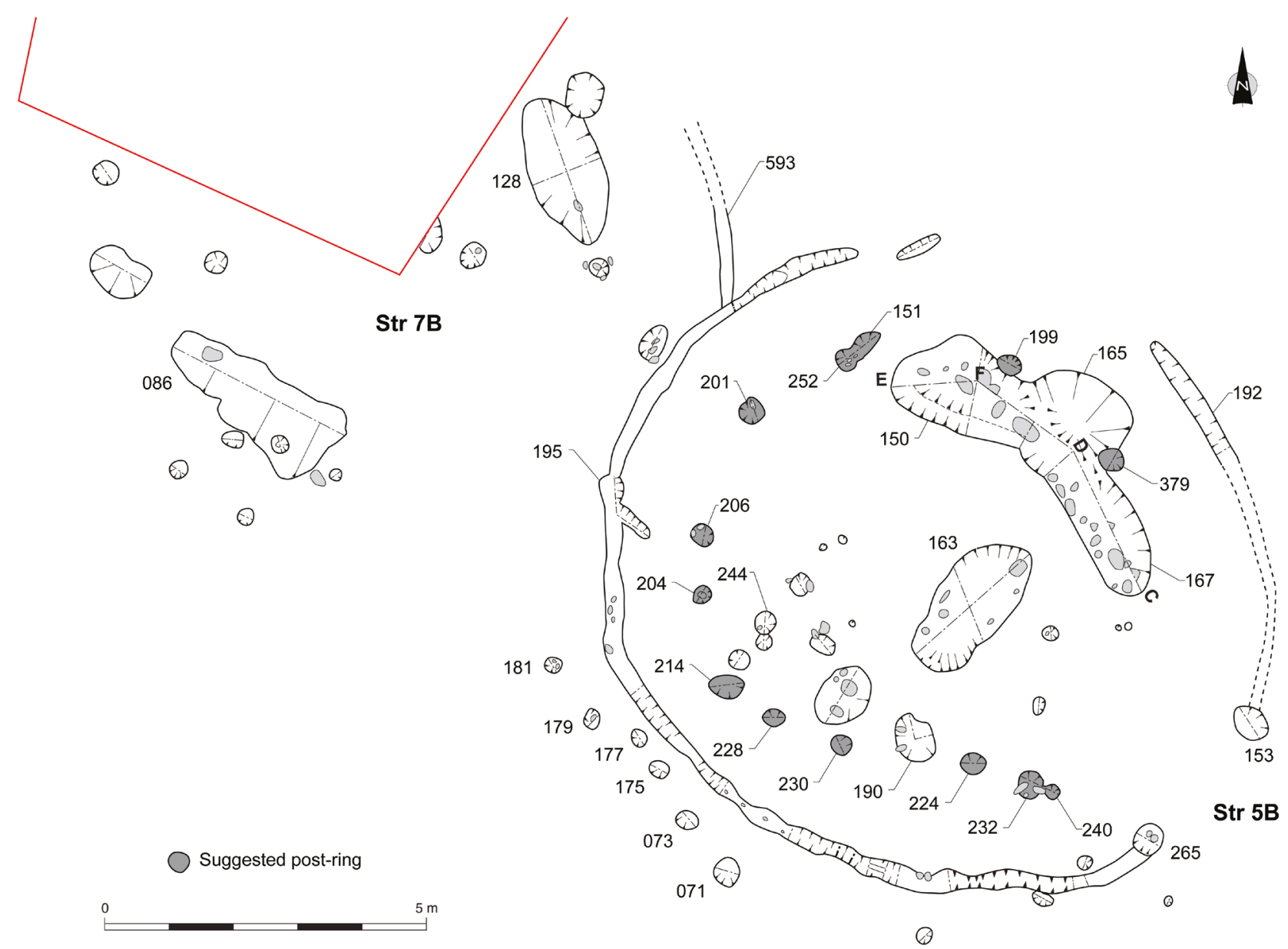

Illus 8 Plans of Structures 5B and 7B, Area B 
as well as a group of three conjoined and a number of internal features, including a possible firepit.

\subsubsection{Description}

The ring groove (192) was an intermittent feature which was truncated on its north and north-east sides. Its dimensions were $c 0.45 \mathrm{~m}$ wide by $0.3 \mathrm{~m}$ deep. An upper fill comprised dark brown-orange silt with flecks of charcoal, and the lower fill was light orange-brown silt. There was one post hole (195) within the ring groove. The structure's southeast entrance was defined by a pair of opposing post holes, 153 and 265, at the terminal ends of the ring groove. The ring groove on its north-west side cut a curvilinear feature (593), which was heavily truncated and could only be seen in plan as a faint stain darker than the surrounding natural subsoil; it was $0.3 \mathrm{~m}$ wide. This curvilinear feature is interpreted as the remains of a probable ring groove of another circular structure (see below, Structure 7B).

The degree of horizontal truncation and the concentration of post holes in the south-west quadrant of the structure make the post ring difficult to define. It is possible that a sequence of 13 post holes represents the post ring (clockwise from the south: 232/240, 224, 230, 228, 214, 204, 206, 201, 151/252, 199 and 379), ranging in size from $0.34 \mathrm{~m}$ by $0.36 \mathrm{~m}$ by $0.08 \mathrm{~m}$ deep to $0.4 \mathrm{~m}$ by $0.75 \mathrm{~m}$ by $0.27 \mathrm{~m}$. The fills of these post holes were generally dark or light brown loosely compacted sandy silt. Post Holes 232/240 possibly represent replacement or support of the original post, as might $151 / 252$. Potentially eight posts $(224,230,214$, $206,201,252,199$ and 379) form a roughly equally spaced set, with the others representing additions or replacements. Post Holes 199 and 379 were found below the fill of Pits 150 and 165 respectively.

There were 21 internal features, which varied in form and ranged in size from $0.1 \mathrm{~m}$ diameter by $0.11 \mathrm{~m}$ deep to $0.94 \mathrm{~m}$ by $2.43 \mathrm{~m}$ by $0.26 \mathrm{~m}$ deep. Three conjoined pits were recorded in the north-east quadrant of the structure (150, 165 and 167 Illus $7 \mathrm{~b} \& \mathrm{c}$ ), which measured $2.2 \mathrm{~m}$ by $1 \mathrm{~m}$ by $0.2 \mathrm{~m}$ deep, $1.5 \mathrm{~m}$ diameter by $0.24 \mathrm{~m}$ deep and $2.4 \mathrm{~m}$ by $1 \mathrm{~m}$ by $0.19 \mathrm{~m}$ deep respectively. The pits were filled with loosely compacted dark brown sandy silt with some charcoal, similar in its characteristics to the fills of the pits in the post hole ring, see above. These features were amorphous, with irregular bases and edges, and were suggestive of wear patterns, rather than deliberately excavated features. The large, roughly central pit (163), dimensions $1.2 \mathrm{~m}$ by $2 \mathrm{~m}$ by $0.26 \mathrm{~m}$ deep, was steep-sided and flat-bottomed and occupied a position in the structure that was suggestive of a firepit, but although there were some charcoal flecks included in its greyish silt fill, there was no evidence of in-situ burning; hence the function of this pit remains undetermined.

\subsubsection{Interpretation and phasing}

The defining feature of Structure 5B was the ring groove. It had an entrance orientated to the southeast, defined by a gap and opposed post holes. This suggests that the ring groove was the foundation slot for the structure's external wall, rather than a drip-gully in which post holes would serve no obvious purpose. A suggested post ring ran approximately concentrically with the ring groove. Two post ring post holes at the edge of the group of conjoined pits appear to have been cut before these features were filled, suggesting that the post ring pre-dates the infilling of these features. It seems likely that Structure 5B represents a single phase of building with some minor post replacement episodes. However, given the nature of the site with its shallow topsoil, which had previously been ploughed, truncation has played a significant part in the survival or otherwise of putative features.

The structure stratigraphically post-dates the curvilinear Feature 593, a feature which may belong to an earlier but similar structure, 7B (see below).

Radiocarbon dating of material from features associated with Structure 5B produced date ranges of 1503-1427 cal вС (95\% probability; UBA-13426) from Post Hole 244 and 1408-1292 cal BC (95\% probability; UBA-13425) from Pit 150.

\subsection{Structure 2B}

\subsubsection{General summary}

This was a post-built structure measuring $8.5 \mathrm{~m} \mathrm{E-W}$ by $9 \mathrm{~m} \mathrm{~N}-\mathrm{S}$ and had an outer and an inner post ring (Illus 9). There was an entrance to the south-east which was framed by four large post holes. There were internal features throughout and a segmented ring ditch to the west and east within the house. 


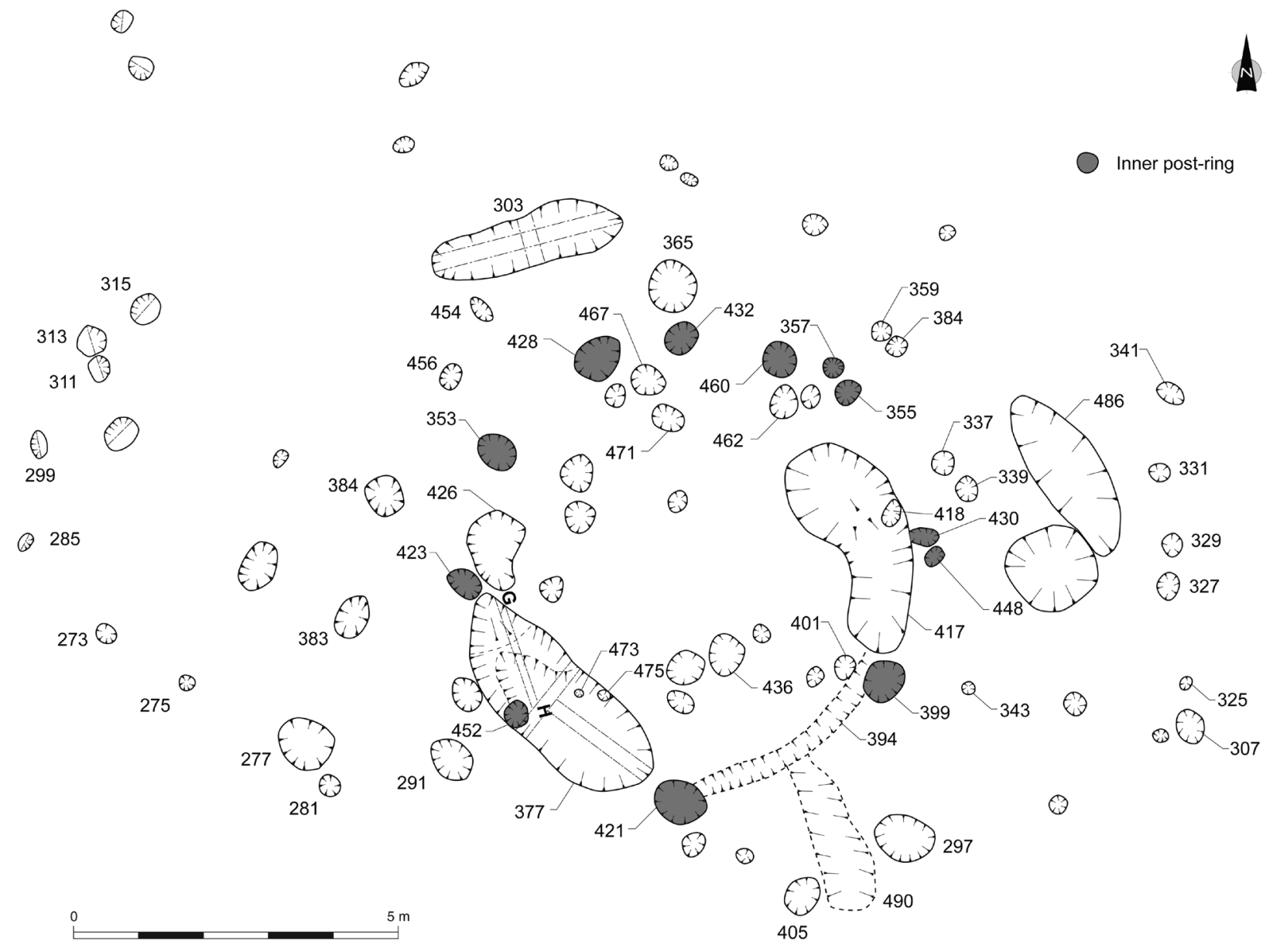

\section{Illus 9 Plan of Structure 2B, Area B}

As with Structure 5B, the concentration and number of internal features made it difficult to determine whether there was more than one phase within this structure. However, at least two possible post rings were identified, but they were only broadly concentric. The fills of pits within both post hole rings can be characterised as loosely compacted dark brown-orange sandy silt.

The discovery of a fragment of a stone 'napkin ring' and two unworked blocks of oilshale within this structure suggests that it may have been used for craft working.

\subsubsection{Description}

The larger post ring ( $9 \mathrm{~m}$ diameter) comprised 12 post holes (405, 291, 384, 456, 454, 365, 359, 384, $337,339,343$ and 297 ) which ranged in size from $0.31 \mathrm{~m}$ diameter by $0.09 \mathrm{~m}$ deep to $0.87 \mathrm{~m}$ by $0.53 \mathrm{~m}$ by $0.3 \mathrm{~m}$ deep. The proximity of 359 and 384 may be taken to indicate that these pits represent a post replacement episode, as does the positioning of 337 and 339.

A possible smaller ring ( $6.6 \mathrm{~m}$ diameter) of 12 post holes was identified $(421,452,423,353$, 428, 432, 460, 357, 355, 430, 448 and 399); these ranged in size from $0.3 \mathrm{~m}$ diameter by $0.13 \mathrm{~m}$ deep to $0.63 \mathrm{~m}$ by $0.94 \mathrm{~m}$ by $0.2 \mathrm{~m}$ deep. The paired Post Holes $357 / 355$ and 430/448 may represent post replacement episodes. Both are close to the post replacements identified in the outer ring, perhaps suggesting a weakness in the structure.

A possible $3 \mathrm{~m}$-wide entrance through the inner post ring could be defined by two opposing post holes (421 and 399; Illus 9). These opposing post holes were linked by a linear feature 394, possibly a threshold. This entrance may have been augmented by a porch defined by Post Holes 405 and 297 to the south. Running between these two post holes, 
Feature 490 looked convincingly like the result of wear, perhaps created by movement into and out of the structure, leading to the possible threshold (394) of the structure.

A putative ring ditch had survived as two large curvilinear pits (377 and 417), and Pit 426 may also be part of the truncated remains of the western ditch. The western ditch (377) measured $3.7 \mathrm{~m}$ by $1.2 \mathrm{~m}$ by $0.2 \mathrm{~m}$ deep and was filled with two deposits (378 and 464; Illus 10a), and the eastern ditch (417) measured $3.5 \mathrm{~m}$ by $1.3 \mathrm{~m}$ by $0.24 \mathrm{~m}$ deep and was filled with a single deposit (416). The fills within these ditches were of loosely compacted mid-brown sandy silt. Pit 377 contained a fragment of a stone napkin ring and a lump of unworked oilshale.

Four features had been cut into the sides and bases of the ditches, three on the west $(452,473$, 475) and one on the east (418). Their stratigraphic relationship with the segments of ring ditch indicates that these were later features excavated after the ring ditch had been infilled. As Pit 452 is cut into Ditch 377 it would indicate that the smaller post ring post-dates the ring ditch, suggesting that there are at least two phases to this structure.

The remaining 18 internal features were mostly located to the north and south sides of the internal space, leaving a relatively uncluttered central floor space. Pit 436 contained burnt bone and charcoal but showed no signs of in-situ burning. Pit 467 contained a lump of unworked oilshale.

Several features clustered around the structure. One notable feature was a large oval pit to the north, 303, which contained a large quantity of pottery (see Section 4.8 below). This flat-bottomed pit measured $1 \mathrm{~m}$ by $5 \mathrm{~m}$ by $0.16 \mathrm{~m}$ and was filled with a single fill of loosely compacted brown sandy silt containing flecks of charcoal. There were no stratigraphic relationships with other features, other than its proximity to the back of the structure. The pottery sherds were from a single vessel, but whether this vessel was deliberately deposited in the pit, either as a broken vessel or an intact one, cannot be determined. The size and elongated shape of the pit did not indicate the pit was a structural foundation and therefore, the function of the pit remains unknown although, together with Pit 486, it may form the remains of a further ring ditch, suggesting perhaps another phase of construction.

Other features include a row of pits, 307, 325, 327, 329, 331 and 341, similar to that seen between Structures $4 \mathrm{~B}$ and $5 \mathrm{~B}$ and of unknown function.

\subsubsection{Interpretation and phasing}

Structure 2B was one of two structures in this area where there was no evidence of a ring groove, the other being Structure 6B immediately adjacent.

(10a) G

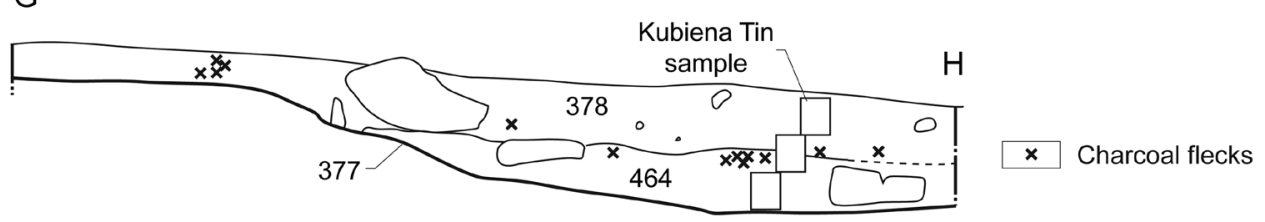

(10b)

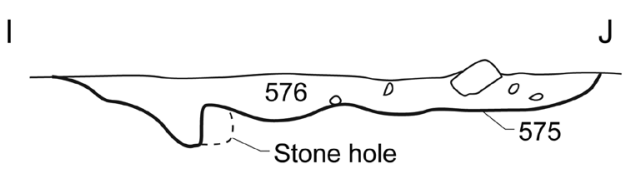

(10c) $\mathrm{K}$

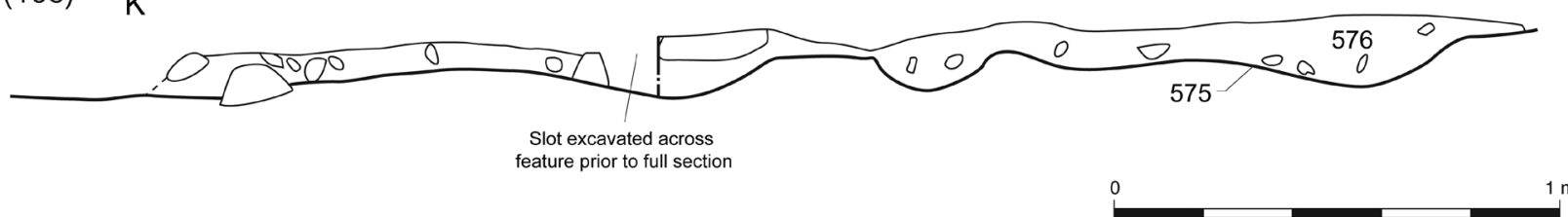


It is possible that a ring groove could have been truncated or eroded away, as evidenced elsewhere in this area. Alternatively, the construction of an outer wall did not require a foundation slot, the wall either being attached directly to the post ring, or tied to the ground by stakes, the associated stake holes having subsequently been truncated.

Some of the numerous pits within this structure can be assigned to probable inner and outer post rings. The proximity of the post rings to each other suggests that they may represent different phases, as it seems unlikely that there is a structural necessity to have two post rings to support a single roof. However, it cannot be ascertained in which order the post rings were built, but the smaller post ring appears to post-date the ring ditch as Post 252 cuts Pit 377, part of the ring ditch.

There was also evidence of post replacements, as demonstrated by Features 359 and 384 . Whether the inner and outer post rings were contemporary remains unproven, and each post ring could in theory represent two different structures built in the same location. However, the positioning of the sets of replacement posts may be one argument against this, as it seems unlikely that two separate structures would fail in the same position when there was no underlying geological cause for it.

The entrance to the ring ditch structure is likely to have been orientated to the south-east, with evidence for a possible porch and threshold.

A fragment of a 'napkin ring', a distinctive EarlyMiddle Bronze Age dress fastener and two unworked blocks of oilshale found in features for Structure 2B suggest that this structure may have been used for craftwork.

\subsection{Structure 6B}

\subsubsection{General summary}

This post-built structure had a diameter of $c 8 \mathrm{~m}$ (Illus 11). Again, truncation made the interpretation of the structure difficult. However, it appears to have

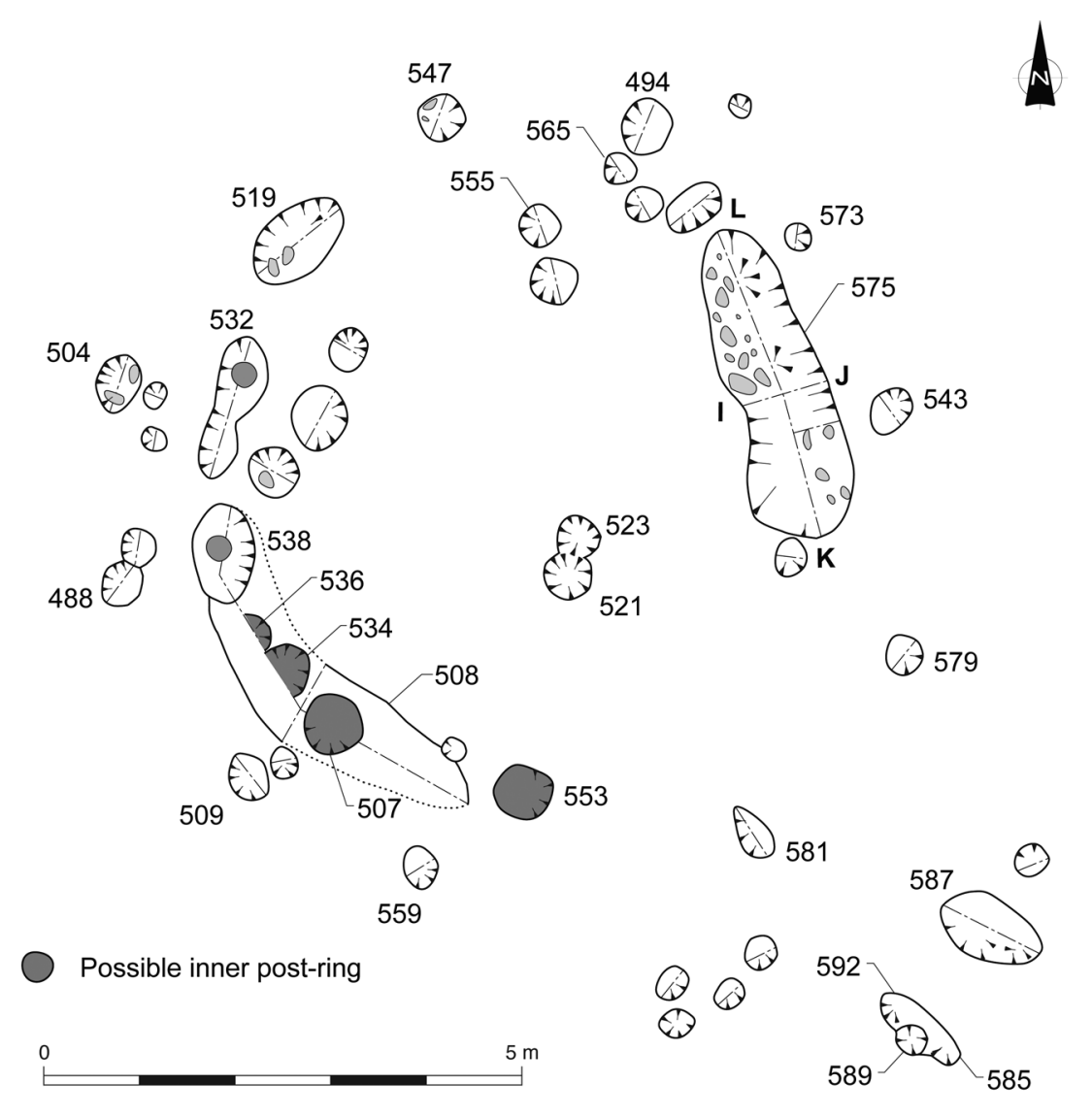

Illus 11 Plan of Structure 6B, Area B 
had an outer post ring, and the possible remains of a second visible as an arc of pits within the west part of the structure. The remains of a possible ring ditch were present on the structure's eastern side. The features of Structure 6B were sealed by a deposit of charcoal-rich black silt.

\subsubsection{Description}

Eleven post holes were identified within the outer ring (clockwise from the north: 547, 494, 573, 543, 579, 581, 559, 509, 488, 504 and 519), which ranged in size from $0.2 \mathrm{~m}$ diameter by $0.08 \mathrm{~m}$ deep to $1.29 \mathrm{~m}$ diameter by $0.23 \mathrm{~m}$ deep. The fills of these pits were loosely compacted light to dark brownorange sandy silt.

The remains of a possible ring ditch (575) were found on the east side of the structure (Illus 10b \& c). The feature measured $3.45 \mathrm{~m}$ by $1.15 \mathrm{~m}$ by $0.15 \mathrm{~m}$ deep and was filled with a loosely compacted dark brown to black silt which contained small fragments of charcoal. A spread of dark soil (508) to the west may be the shallow remnant of a ring ditch in that half of the structure.

An arc of at least eight pits, running concentric with the outer post ring, may be the remains of another post ring $(553,507,534,536,538,532$, 555 and 563). These features ranged in size from $0.5 \mathrm{~m}$ diameter by $0.18 \mathrm{~m}$ deep to $0.45 \mathrm{~m}$ by $0.58 \mathrm{~m}$ by $0.28 \mathrm{~m}$ deep. The fills of these pits within the inner post ring were similar to the fills within the outer post ring, characterised by loosely compacted brown-orange silt. Alternatively, they may represent pits within a ring ditch.

An entrance was not clearly discernible, however an elongated pit (587) and a group of pits (585, 589 and 592) could have formed an entranceway to the south-east.

There were 14 other features internal to the structure which ranged in size from $0.2 \mathrm{~m}$ by $0.25 \mathrm{~m}$ by $0.15 \mathrm{~m}$ deep to $3.5 \mathrm{~m}$ by $1 \mathrm{~m}$ by $0.15 \mathrm{~m}$ deep. The function of these features is unknown. However, Pits 521 and 523 may represent a post replacement; they occupy a relatively central position within an otherwise clear floorspace and may have been the foundation for a central structural post.

\subsubsection{Interpretation and phasing}

This structure may have had an outer and inner post ring, although a structure this size would not have had, on structural grounds, any need for two post rings. Either these post rings represent two phases of construction on the site, or the inner one is merely a group of pits related to the ring ditch.

\subsection{Structure 7B}

\subsubsection{General summary}

A further possible structure was identified at the north-west limit of the excavation, the principle components of which were two large curvilinear pits, possibly the remains of a ring ditch, and a segment of a curvilinear feature, the remains of a possible ring groove (Illus 8).

\subsubsection{Description}

This possible structure was identified to the northwest of Structure 5. It was not fully exposed as it continued under the baulk. The curvilinear pits $(086$ and 128 ) measured $1 \mathrm{~m}$ by $2.81 \mathrm{~m}$ by $0.11 \mathrm{~m}$ deep and $1.12 \mathrm{~m}$ by $2.22 \mathrm{~m}$ by $0.2 \mathrm{~m}$ deep respectively. The distance between the outer edges of Pits 086 and 126 was $c 7 \mathrm{~m}$, a similar distance to that between the ring ditch segments in Structure $2 \mathrm{~B}$ and across the ring ditch in Structure 4B, and the two pits were reminiscent of truncated ring ditches seen elsewhere on the site. The pits were filled with moderately compacted dark brown sandy silt with inclusions of fragments of charcoal and burnt bone. Two sets of radiocarbon dates were produced from these pits: 1391-1216 cal вс (95\% probability; UBA13423) and 1407-1271 вс (95\% probability; UBA13424) from Pit 128 and 1381-1210 cal BC (95\% probability; UBA-13421) and 1431-1316 cal вС (95\% probability; UBA-13422) from Pit 086.

The curvilinear feature (593) survived as a $2.5 \mathrm{~m}$ long stain in the subsoil with no measurable depth, cut by the ring groove of Structure 5B to the south and petering out to the north. It is likely to represent the remains of a ring groove.

\subsubsection{Interpretation and phasing}

This possible structure was defined by the following elements: ring ditches, pits and a short length of a 
curvilinear feature. In plan, these features appear similar to, though more vestigial than those of the later Structure 5B, which cut one element of the group. There was no evidence that more than one phase of construction had taken place on this site and potentially $5 \mathrm{~B}$ could represent a replacement in a slightly different position.

\subsection{Structure $3 C$}

\subsubsection{General summary}

This structure comprised a ring ditch with the later intermittent remains of a possible ring groove which survived as curvilinear segments and post holes following the same alignment (Illus 12).

\subsubsection{Description}

The intermittent remains of a possible ring groove, c $10 \mathrm{~m}$ diameter $\mathrm{E}-\mathrm{W}$, survived as curvilinear segments $(089,204,283)$ and post holes following the same alignment $(190,192,194,224,021,023$,
019, 037, 035 and 039) and which ranged in size from $0.29 \mathrm{~m}$ by $0.31 \mathrm{~m}$ by $0.08 \mathrm{~m}$ deep to $0.4 \mathrm{~m}$ by $0.48 \mathrm{~m}$ by $0.15 \mathrm{~m}$ deep. The curvilinear segments of this feature $(089,204$ and 283) measured $6 \mathrm{~m}$ by $0.2 \mathrm{~m}$ by $0.1 \mathrm{~m}$ deep, $1.3 \mathrm{~m}$ by $0.15 \mathrm{~m}$ by $0.1 \mathrm{~m}$ and $1.5 \mathrm{~m}$ by $0.1 \mathrm{~m}$ by $0.02 \mathrm{~m}$ deep respectively. The various segments of this putative ring groove were all filled with dark brown sandy silt with charcoal inclusions. The surviving post holes may represent part of a contiguous series of posts secured into a ring groove foundation, with only the base of its cut surviving. The conjoined nature of Post Holes 037, 035 and 039 is particularly suggestive of this form of construction.

The scant remains of another curvilinear gully (106) survived to the east of 089, suggesting that there was another ring groove feature running concentrically with the first. Within the ring groove a post ring of at least 12 pits was identified $(003,005$, 007, 017, 148, 051, 059, 061, 063, 095, 067 and 079 ), which ranged in size from $0.23 \mathrm{~m}$ by $0.24 \mathrm{~m}$ by

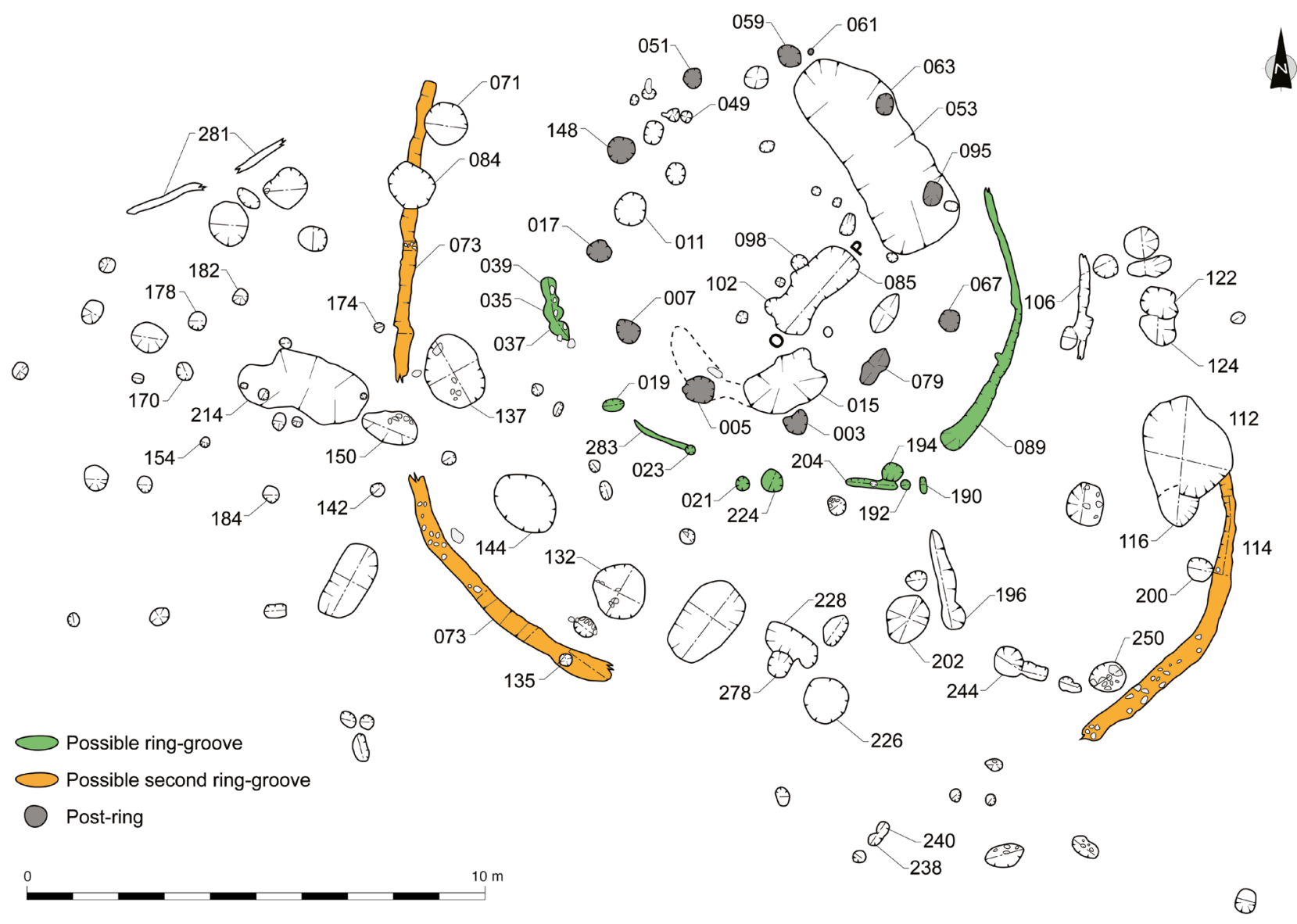

Illus 12 Plan of Structure 3C, Area C 
$0.11 \mathrm{~m}$ deep to $0.8 \mathrm{~m}$ diameter by $0.39 \mathrm{~m}$ deep and were filled with loosely compacted sandy silt which varied in colour from grey to dark brown. Pits 063 and 095 also cut a ring ditch (053), suggesting that the post ring post-dates the ring ditch.

The ring ditch (053) was situated on the east side of the structure, measured $5 \mathrm{~m}$ by $2 \mathrm{~m}$ by $0.25 \mathrm{~m}$ deep and was filled with a single deposit of firm dark brown silt (054). Together with Pit 015, these two pits are thought to represent the remnants of a segmented ring ditch. Pit 015 was very truncated and during excavation the extent of the surviving pit was thought to be bigger based on its fill, which extended further to the north-west as a shallow spread of the same material. Pit 015 would then have mirrored Pit 053.

Other features inside the area enclosed by the ring groove were generally small, with the exception of 085 . Although there was no evidence of in-situ burning, this near-central feature (Illus 13) was interpreted as a cooking pit on the basis of its position within the structure and its charcoal-rich deposits, which contained both pottery sherds and burnt bone. Five small features were present on the northern side of Pit 085, one of which (102) was cut into its side and one (098) was cut by the cooking pit. These five features may represent a structure associated with cooking, perhaps for suspending vessels over a fire. The functions of the remaining internal pits were not established.

The intermittent remains of a curvilinear gully were present on the south-east and the west (073 and 114) and external to the circular structure. This feature measured $0.2 \mathrm{~m}$ wide by $32 \mathrm{~m}$ (surviving length) by $0.1 \mathrm{~m}$ deep. The gully had survived as a slight stain in the subsoil on the north and north-east, completing a circle, but this vestigial evidence was lost owing to weather conditions during the excavation. A single pit, possibly a post hole (135), measuring $0.3 \mathrm{~m}$ by $0.4 \mathrm{~m}$ by $0.12 \mathrm{~m}$ deep was found cut into the base of the southern part of 073 . The feature was also cut by Pits 112, 084 and 071, making 073/114 stratigraphically earlier than these pits (but see radiocarbon dates, Section 4.10 below). The gully may possibly have been a foundation slot for an enclosure palisade, creating a narrow yard of irregular width between the house and enclosure.

Enclosed by the curvilinear gully $(073 / 114)$ was an arc of seven pits ranging in size from $0.5 \mathrm{~m}$ by $0.4 \mathrm{~m}$ by $0.31 \mathrm{~m}$ deep to $1.8 \mathrm{~m}$ by $2 \mathrm{~m}$ by $0.4 \mathrm{~m}$ deep (071, 084, 137, 144, 132, 228 and 202). Most respected the curvature of the inner ring groove and the outer gully, but three pits cut through the remains of curvilinear Feature 073/114. Pits 228, 112 and 124 were also cut respectively by later Pits 278, 116 and 122. While some of the pits may be contemporary with the use of the roundhouse and putative palisade, it is clear that at least some were later.

There were several features in proximal association with Structure 3C whose relationships with each other were not clear. A few of these features were present on the inside of the curvilinear feature $(073 / 117)$, but the majority were found outside in two concentrations to the west and south (Illus 12).

The cluster of ten features immediately south of $073 / 117$ was generally uniform and the features show no relationship in plan except proximity, although Pits 238 and 240 appeared to be conjoined and may represent a post replacement event.

The features clustered immediately to the west of $073 / 117$ were not uniform in size, shape or deposits contained therein. Pit 150 occupied a break in the curvilinear gully (073), although it cannot be said whether it pre- or post-dated the gully as there was no stratigraphic relationship

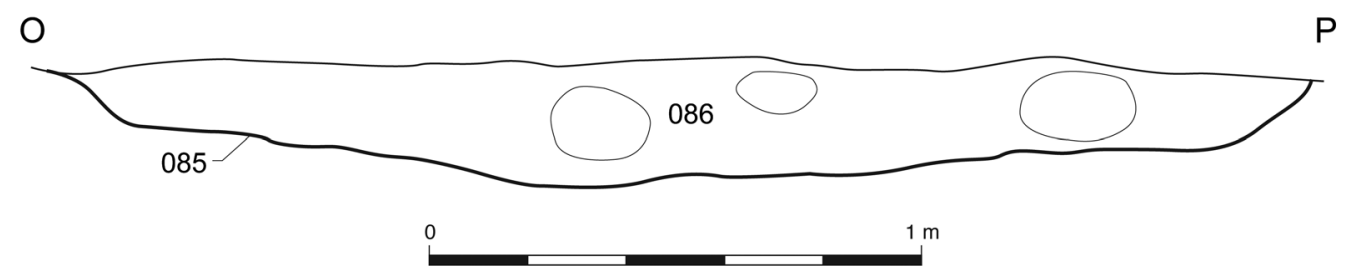

Illus 13 Selected sections of Structure 3C, Area C 
between them. Pit 214 was surrounded by six smaller pits, three of which were excavated into the pit edge. A similar arrangement, interpreted as a cooking pit, was associated with Pit 085 within Structure 3C. Small amounts of charcoal and pottery were retrieved from the fill of 214 , but otherwise there was little compelling evidence that this pit was also a cooking pit. A putative ring of small pits or post holes $(142,184,154,170,178$, 182 and 174) encircled Pit 214. Two sections of a linear feature, 281, were also noted on the north side of this cluster of features and are similar to the surviving remnants of the inner ring groove (089) of Structure 3C. Although these isolated features attest to prehistoric activity, what form this took could not be firmly established; perhaps the features to the west of Gully 073/117 could represent the remains of another structure.

\subsubsection{Interpretation and phasing}

The features making up this structure represent more than one phase and there are identifiable components within the group that indicate at least one round structure, including a ring groove, post ring and ring ditch. The interpretation of structural elements and their phasing was confounded by the closely grouped nature of the features, their unclear relationships, and by the number of features within this group.

\subsection{External features in Area B}

Sixty-four features could not be assigned to the circular structures (Illus 5). They varied in form and tended to group around the structures. The function of these features is difficult to determine. The larger pits may have been for storage and some of the smaller pits may have been post holes for tethering poles or possibly windbreaks and boundaries, such as the row of six between Structure $4 \mathrm{~B}$ and Structure 5B $(171,173,175,177,179$ and 181, Illus 6 and 8) or another, east of Structure 2B (307, 325, 327, 329, 331 and 341, Illus 9). A group of seven post holes forming an approximate right-angle $(281,275$, $273,285,299,311$ and 315, Illus 9) to the west of Structure $2 \mathrm{~B}$ may represent the vestigial remains of a further roundhouse.

\subsection{Artefacts}

\subsubsection{Pottery}

Melanie Johnson

A large assemblage of MBA/LBA pottery was recovered during the excavations in this area, the largest of all of the excavated areas, comprising 509 sherds weighing over $10.6 \mathrm{~kg}$ (Table 3 ). The average sherd weight is high, at $20.8 \mathrm{~g}$, due to the number of thick base and rim sherds.

The sherds were unevenly distributed between the structures, with the vast majority coming from contexts associated with Structure 2B and Structure 3C.

Fabrics were generally coarse, sandy and with up to $30 \%$ sand and grit inclusions and stones recorded up to $12 \mathrm{~mm}$ in size. Wall thickness ranged between $6 \mathrm{~mm}$ and $17 \mathrm{~mm}$, with base thickness up to $21 \mathrm{~mm}$. Colours tended to be greys, browns and oranges. Surfaces tended to be finished by smoothing, and finger-marking is often visible. Many of the sherds are abraded.

\section{Structure $2 B$}

A couple of contexts (east Ring Ditch 417, within Structure 2B, and Pit 303, to the north of Structure 2B) contained large deposits of pottery, between them containing $72 \%$ of the pottery from this building by weight. Other pottery-bearing contexts from within this building were a variety of pits and post holes $(353,399,405,423,426,436,462$, 471 ), and the portion of ring ditch on the west side (377). Others derived from a pit to the west (277), and an elongated pit to the east (486), both of which lie outside the structure.

The diagnostic sherds include very thick as well as thinner rounded rims (P24 Illus 14; P68),

\section{Table 3 Pottery from Areas B and C}

\begin{tabular}{lrrc} 
Structure & No. sherds & Wt $(\mathrm{g})$ & $\begin{array}{c}\text { No. } \\
\text { vessels }\end{array}$ \\
2B & 312 & 6448 & 53 \\
\hline 3C & 119 & 3134 & 52 \\
\hline 4B & 42 & 493 & 8 \\
\hline 5B & 7 & 146 & 6 \\
\hline 6B & 8 & 102 & 6 \\
\hline Other & 21 & 281 & 9
\end{tabular}


flat-topped rims (P70), expanded to either side (P51 Illus 14; P80), slightly everted (P73), flat-topped bowls (P27 Illus 14; P76; P78), ridges on the exterior (P45 Illus 14), a barrel-shaped vessel with rounded rim (P64 Illus 14), inturning and necked (P79), and flat bases (P49). Rim diameters of $130 \mathrm{~mm}, 180 \mathrm{~mm}$, $220 \mathrm{~mm}, 270 \mathrm{~mm}$ and $280 \mathrm{~mm}$, and a base diameter of $180 \mathrm{~mm}$ were recorded.

Substantial portions of several vessels were recorded. P27 from Pit 303 consisted of 37 sherds from an open bowl with a flat-topped rim, diameter $280 \mathrm{~mm}$ (Illus 14). From initial site cleaning, P79 consisted of part of a vessel with a slightly angled inturning rim, a closed mouth, a barrel/globular body and short concave neck.

P64 from Context 417 consisted of just 11 sherds weighing $1626 \mathrm{~g}$ (Illus 14). This slightly barrelshaped vessel had a neutral rounded rim of diameter $220 \mathrm{~mm}$. P65, also from C417, consisted of 43 body sherds weighing $1219 \mathrm{~g}$.

P78 was an open bowl with a flat-topped rim, and the neck kinks in to give a carinated shoulder. A fingertip has been run along the vessel above the carination (Illus 14).

\section{Structure 3C}

Within Structure 3C, pottery was recovered in small quantities from various pits and post holes within the structure itself $(011,049,059,085)$, located between the inner ring groove and the outer gully $(144,196,200,202,226,228,244,250,278)$, or external to the gully (238). Only a single sherd was recovered from the portion of Ring Ditch 053 on the east side of the building, in contrast to Structure $2 \mathrm{~B}$, where the equivalent context was prolific. About a third of the pottery assemblage was recovered as surface finds during site preparation and so cannot be tied to individual features. The diagnostic sherds include rounded and flat-topped upright rims (P92 Illus 14; P129, P136, P130), slightly necked rims (P88, P100 Illus 14), rims slightly expanded to either side (P91 Illus 14; P80), expanded and necked (P134 Illus 14; P131), with ridges on the exterior (P132, P135 Illus 14; P119), thick and inturning rims (P133 Illus 14), and flat and footed bases (P81 Illus 14; P111). Rim diameters of 150$180 \mathrm{~mm}, 220 \mathrm{~mm}, 240 \mathrm{~mm}$ and $290 \mathrm{~mm}$, and a base diameter of $140 \mathrm{~mm}$ were recorded.

Body sherds with fingertip grooves on the exterior
(P85, P128) may be the remains of an externally ridged rim.

There were fewer examples of substantial portions of vessels. P100 has just over half of the rim circumference surviving from a flat-top, upright neutral vessel, very slightly necked (almost imperceptible) with a diameter of $170 \mathrm{~mm}$.

An intrusive sherd from an earlier period was noted, in the form of a Beaker rim sherd (P120) recovered during cleaning of Structure $3 \mathrm{C}$. This fine, tapered and slightly flaring rim sherd, with a diameter of $120 \mathrm{~mm}$, was decorated with two rows of closely spaced impressions (possibly made with the end of a bird bone or reed), then two horizontal grooves. Beaker activity on the site is also attested to in the Watching Brief Area X (Section 3).

\section{Structure $4 B$}

Most pottery within Structure $4 \mathrm{~B}$ came from the upper fill (009) of the ring ditch (008). This comprised 43 sherds, including four rim sherds and six base sherds. The base sherds came from the same vessel, along with ten body sherds, and are from a thick base with a convex interior. A thick flat-topped rim (P6 Illus 14) has external ridges, while a thick rim with a slight internal bevel was found with a possible base and several body sherds (P9). A small, thin rounded rim sherd was also found, which is possibly Late Neolithic in date rather than Bronze Age. Further plain body sherds were recovered from Spread 044 and Post Hole 056. A large elongated pit (005) just to the west of Structure $4 \mathrm{~B}$ contained a small amount of pottery, just three sherds from two different vessels, one of which was a thick, slightly rounded rim.

\section{Structure $5 B$}

Only seven sherds were recovered from Structure 5B. One plain body sherd came from 151, five from 163 , and one base sherd from 190, all of which are pits/post holes within the building.

\section{Structure $6 B$}

A small assemblage was also recovered from Structure 6B, most coming from Post Hole 507 on the south-west side of the building. These included three base sherds from two different vessels with slightly footed bases, one of which had a diameter of $80 \mathrm{~mm}$, and a fragment of rounded rim. A small rim sherd was found in 509, 
Structure 2B

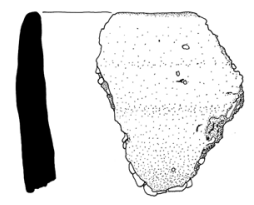

P24
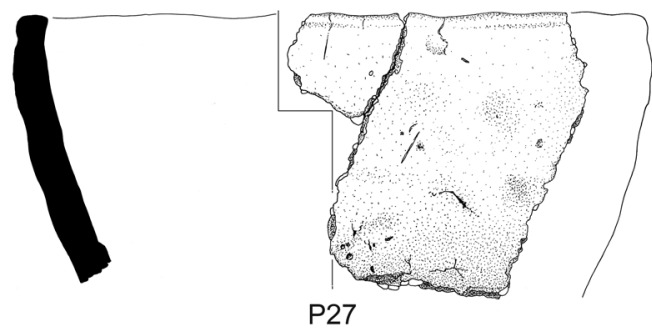

P27

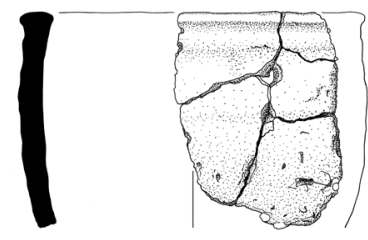

P51

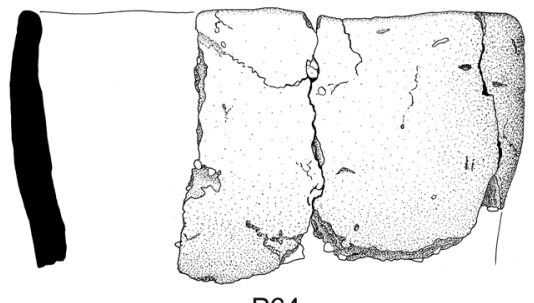

P64

\section{Structure $3 C$}

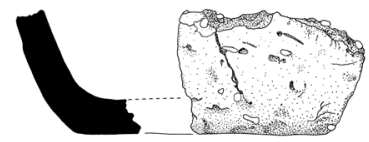

P81

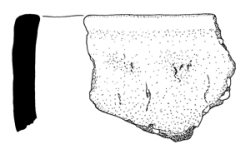

P92
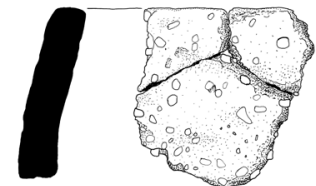

$\mathrm{P} 133$
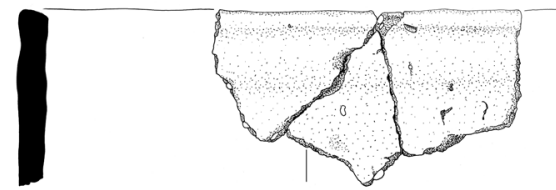

P88
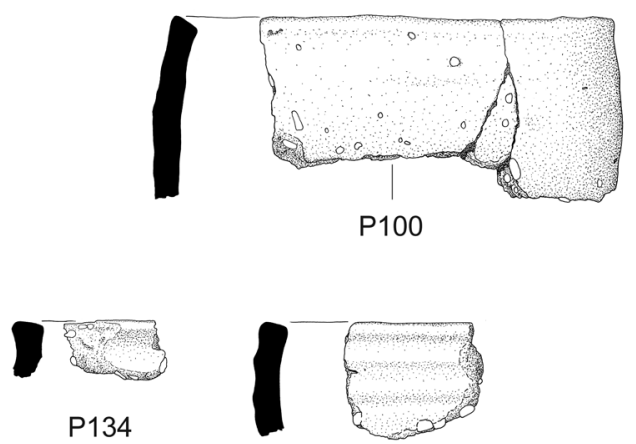

P135

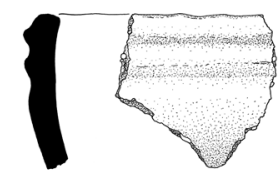

P45

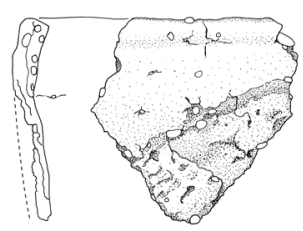

P78

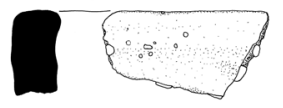

P91

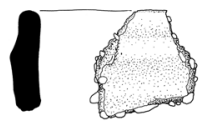

P132

\section{Structure 4B}

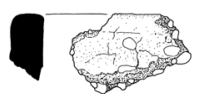

P6

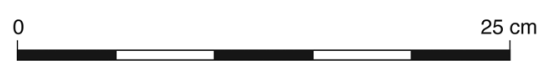

Illus 14 Pottery from Areas B-C

also to the south-west, and a plain body sherd in 521, a post hole in the centre of the building.

\subsubsection{Lithics \\ Ann Clarke}

This was the most productive area for stone finds, with small numbers coming from pits or post holes of Structures 2B, 3C, 4B and 5B as well as some external features.

The flint is an undistinguished assemblage comprising mainly chips, chunks and very small flakes. Where evidence for knapping technique survives it suggests the use of prepared flat platforms. A single flake from Pit 436 in Structure 2B was 
retouched to form a small scraper of a horseshoe/ thumbnail shape - this was later burnt and broken before being deposited in the pit.

Of most interest are four flakes of fine-grained sandstone that were found together in Post Hole 401 of Structure 2B (Illus 15a-d). The larger flake was detached from a multi-platform flake core and there are three smaller flakes, one of which has steep edge retouch down one side and across one end to form a shallow scraper. It is most likely that these flakes all came from the same stone blank. A larger corticated sandstone flake came from the eastern ring ditch (417, Fill 416) in Structure 2B.

Though the evidence from the flaked lithics is slim, the presence of flake manufacturing techniques and the shape of the scrapers would suggest a date from the Late Neolithic to the Middle Bronze Age for the formation of the assemblage. Given this wide dating for the lithics it is uncertain whether they could be residual from earlier activity or not, however, the group of flakes of fine-grained sandstone in one feature would indicate that these at least were made and used during the occupation of the site.

Unrelated to the above group is a large sandstone flake from an upper fill, 048, of the ring ditch of Structure 4B (Illus 15e). This is simple in shape and manufacture but bears a distinctive denticulate edge, most likely the result of edge damage from use wear. The use of large sandstone flakes is common at sites in the Northern Isles dating from the Neolithic through to the Early Iron Age (Clarke 2006). They are considerably less well known on Scottish sites but recently published examples are from Early
Bronze Age contexts at Kilellan, Islay (Clarke 2005) and an Iron Age and Romano-British enclosure at Woodend Farm, Dumfriesshire (Banks 2000). The context of this sandstone flake, in the postabandonment ring ditch fill of Structure 4B, could indicate a similar Middle Iron Age date for its fill.

\subsubsection{Coarse stone artefacts \\ Ann Clarke}

Two perforated stones were found during initial cleaning over Structure 3C. One was a simple flat oval pebble with a circular hole pecked in the centre of the face with a weight of $25 \mathrm{~g}$ (Illus 16a). A possible shallow smoothed notch on the inside of the hole may indicate that the stone was suspended in some way, as a weight rather than having been used as a spindle whorl. The larger weight $(650 \mathrm{~g}$; Illus 16b) has a wide and deep biconical crosssection formed by pecking from both faces and the hole is small, just $5 \mathrm{~mm}$ in diameter, which would mean that a thin but strong twine would have been needed to suspend this weight.

A probable unfinished weight came from the curvilinear feature (073) in Area C. This large cobble was broken across the width truncating a deep pecked hollow on each face (Illus 16c). It is likely that the breakage occurred during the manufacture of a perforated weight intended to be similar to the larger one above. Breakage during manufacture must have been quite common - a similar broken weight is illustrated from a Bronze Age roundhouse in Sutherland (Dunbar 2007, illus 14).

A large anvil stone was placed in Pit 417 of Structure 2B (Illus 16d). On one face a wide
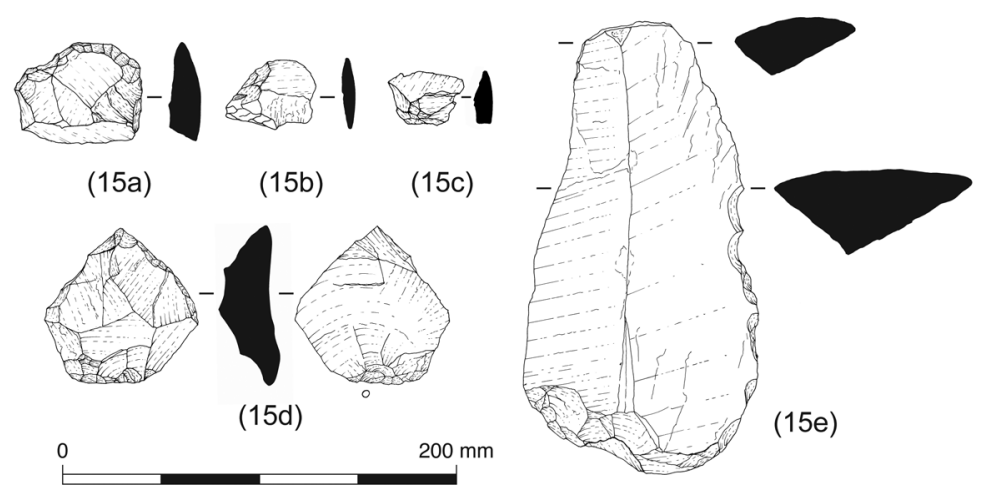

Illus 15 Lithic artefacts of sandstone from Area B 


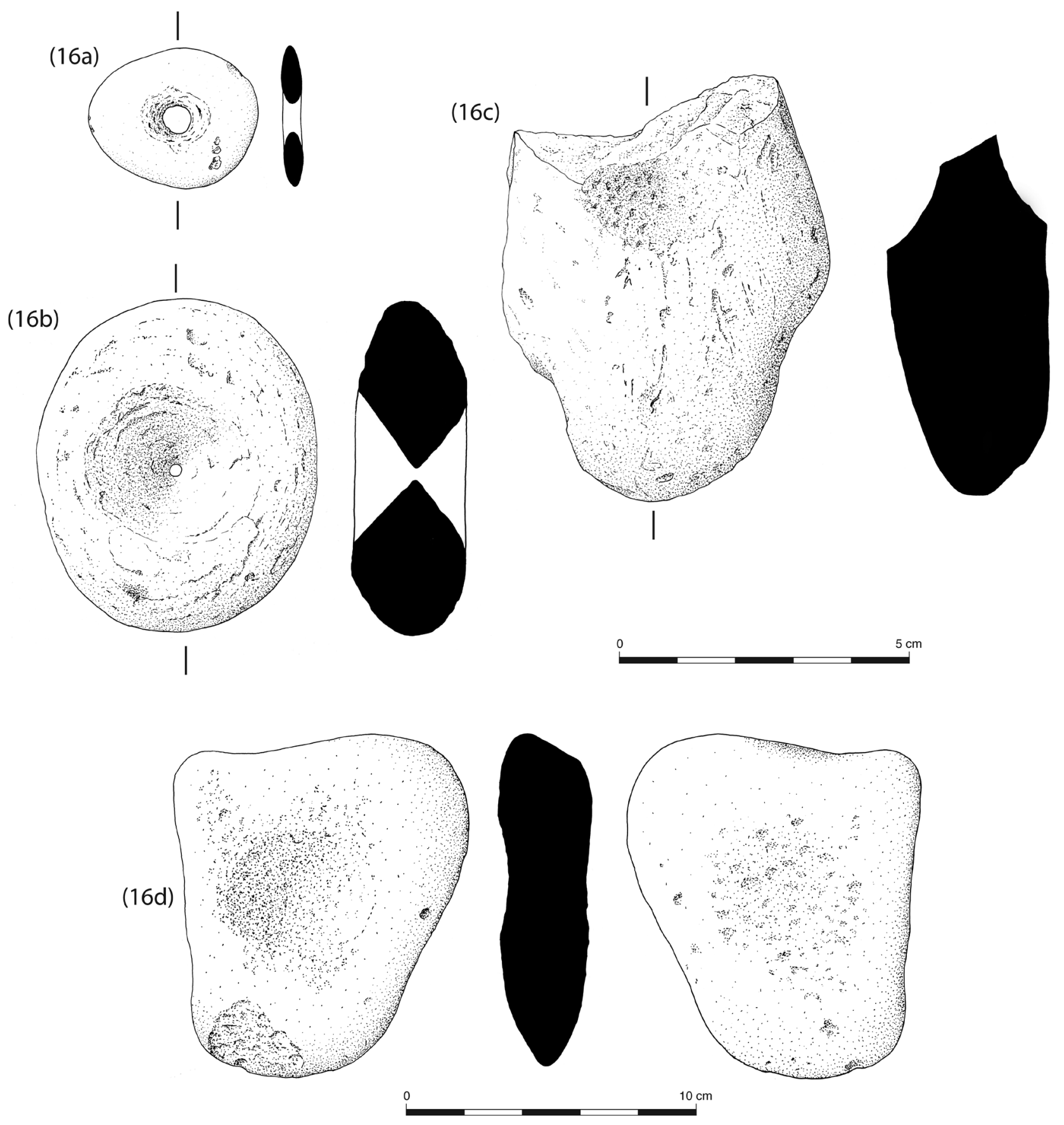

Illus 16 Coarse stone from Areas B and C

spread of pecking forms a shallow dished hollow, but its rough interior indicates that it could never have been used as a pivot stone. Spreads of pecking are also placed on the underside but these do not form hollows. This was most likely used as some kind of anvil stone - perhaps it played a role in the manufacture of the cannel coal artefacts; fragments of a 'napkin ring' came from the same context (see
Hunter, Section 4.8.4 below) and worked fragments from other areas of Structure 2B.

A small hammerstone with light pecking and flake damage on one end had been deposited in Pit 163 in Structure 5B.

A fragment of sandstone with naturally produced tunnels and perforations appears to have been burnt and has slag adhering to the interior of the holes. It 
was found in Post Hole 003 in Structure 4B and was most likely involved in some sort of metalworking activity.

\subsubsection{Shale and cannel coal \\ Fraser Hunter}

One item of jewellery in black organic-rich stone was recovered from Structure 2B: a broken 'napkin ring'. Two unworked blocks of oil shale were also recovered from Structure 2B, suggesting import of raw materials. Most unusual is the fragmentary 'napkin ring', a distinctive Early-Middle Bronze Age type of dress fastener (Hunter 1998); this example sits at the northern edge of the distribution.

The two lumps of shale point to import of raw material. These latter differ from the 'napkin ring', which appears to be cannel coal, but both raw materials are locally exotic; the nearest suitable geological deposits (Coal Measures) are south of the Ochils, in the Central Coalfield (Cameron \& Stephenson 1985: 84-91, fig 25). No specific accessible outcrops have been identified, but geological mapping indicates sources could be available within $c 10-15 \mathrm{~km}$. There is a thin scatter of black organic-rich stone ornaments from later prehistoric sites in Perthshire (eight other find-spots are known to the writer), but the only other site with evidence of on-site working is the Iron Age fort of Castle Law, Abernethy; finds in the National Museums of Scotland include a block of part-worked material (NMS GP 22). As with Gleneagles, this is not too far from potential sources, with the Fife coalfields being some $20 \mathrm{~km}$ distant; for sites in central and northern Perthshire, the distances to sources would have been much greater. The working evidence from Gleneagles and Abernethy indicates a willingness by the inhabitants to procure resources within $10-20 \mathrm{~km}$ of the site, whether directly or through intermediaries.

\section{Catalogue}

'Napkin ring', badly broken during excavation; the five major fragments can be joined to form about a third of the ring, split horizontally with the lower face lost. As is usual, the flared, slightly angled upper surface and perforation are lightly polished, while the concave outer face (which would be hidden in use by attached textile or cordage) has extensive fine
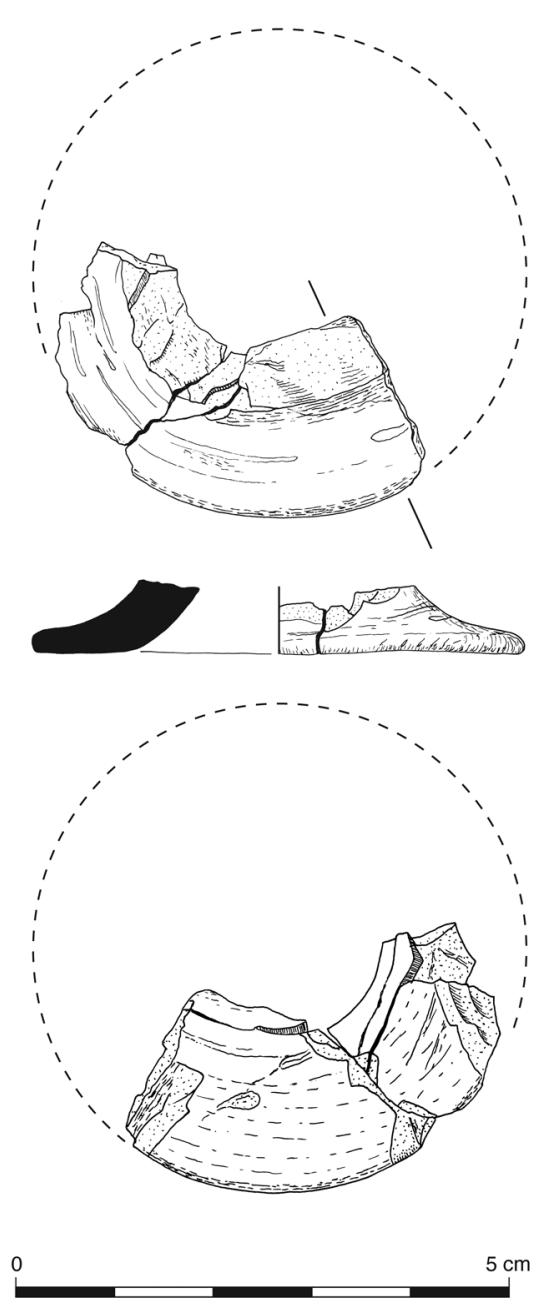

\section{Illus 17 'Napkin ring' from Area B}

circumferential abrasion scars. Probably a compact cannel coal. D c $50 \mathrm{~mm}, \mathrm{H} 18 \mathrm{~mm}$, W $16 \mathrm{~mm}$, perforation $\mathrm{D} c 18 \mathrm{~mm}$. Structure 2B, east Ring Ditch 417 (Illus 17).

Two lumps of tabular oil shale, unworked but non-local and thus probably imported as raw material: 82 by $71 \mathrm{~mm}$ by $18 \mathrm{~mm}, 131 \mathrm{~mm}$ by $73 \mathrm{~mm}$ by $24 \mathrm{~mm}$. Structure 2B, west Ring Ditch 377 and Post Hole 467 (not illustrated).

\subsection{Environmental evidence}

\subsubsection{Calcined bone}

\section{Sue Anderson}

Seventy-five contexts in Area B produced a total of $103.3 \mathrm{~g}$ of bone. Structure 2B produced $8.85 \mathrm{~g}$, of which 6.9g was from Pit 436. From Structure 4B there was $18.5 \mathrm{~g}$, of which the largest concentration was again from a central pit (134). Only $1.8 \mathrm{~g}$ 
was recovered from Structure 5B. Structure 6B produced the largest quantity $(29.4 \mathrm{~g})$, with small concentrations in Pits 507 and 521, and possible Ring Ditch 575. The remaining 8.65g came from five external features. In general the fragments were small and abraded, but a few larger pieces could be identified as large mammal, including pieces of rib and skull, and there were a few tiny fragments from Structure 2B which were probably from a small rodent or amphibian.

A very small quantity of bone was recovered from eight features in Structure 3C (6.1g), three external features $(0.9 \mathrm{~g})$, one internal feature $(<0.1 \mathrm{~g})$ and the palisade $(<0.1 \mathrm{~g})$. With the exception of one large fragment from Pit 085 which was certainly animal, none of this group was identifiable.

\subsubsection{Charcoal \\ Michael Cressey}

Sixty samples of charcoal were analysed from this area, of which 14 were from Structure 2B, six from Structure 4B, four from Structure 5B, 21 from Structure 6B, 12 from Structure 3C and three from other contexts. The numbers of identifications by species for each of the structures are shown in Table 4. A total of 636 identifications $(534.4 \mathrm{~g})$ were made, of which two $(0.2 \mathrm{~g} ; 0.03 \%)$ were alder, 80 were birch (127g; 23.8\%), 277 (133.3g; 24.9\%) were hazel and $277(273.9 \mathrm{~g} ; 51.3 \%)$ were oak.

\subsubsection{Charred grain \\ Mhairi Hastie}

A total of 251 bulk samples were recovered from Areas B and C, of which 32 produced small quantities of grain.
The majority of the grains were identified as barley. None was sufficiently preserved to determine whether they were the naked or hulled varieties. One possible wheat grain and one possible oat grain were also recovered. A small quantity of weed seeds, charred fragments of hazelnut shell and occasional rhizomes were present along with the cereal grain. The weed seeds were generally typical seeds of arable fields, including corn cockle, hemp nettle, ribwort, buttercup and persicaria.

A low-level spread of abraded plant remains was found in both internal and external features associated with the five circular structures. There does not appear to be any specific meaning to the distribution of plant remains, instead the plant debris was present in a variety of features including pits, post holes and the remains of ring ditches. No large concentrations of plant remains were uncovered in these excavated areas to suggest any large-scale burning incidents.

This sparse but uniform spread of highly abraded burnt material has been noted at many prehistoric roundhouse sites throughout Scotland; recent examples include Kintore (Holden et al 2008) and Birnie (Hastie 2005). These are normally interpreted as the reworked and diluted remnants of debris produced by daily activities, including a mixture of grain accidentally charred during small-scale corndrying, discarded or spoilt food deposited on the fire/hearth, and burnt food from floor sweepings, all of this material being trapped in open pits and ring ditches, and accumulating in post holes as the post decayed.

Table 4 Charcoal distribution by species, Areas B and C

\begin{tabular}{lrrrrrrrrrrrr} 
Species & Str2B & \multicolumn{3}{c}{ Str4B } & \multicolumn{3}{c}{ Str5B } & \multicolumn{3}{c}{ Str6B } & \multicolumn{3}{c}{ Str3C } & \multicolumn{3}{c}{ Other } \\
& No. & Wt $(\mathrm{g})$ & No. & Wt (g) & No. & Wt (g) & No. & Wt (g) & No. & Wt (g) & No. & Wt $(\mathrm{g})$ \\
\hline Alder & & & & & & & 1 & 0.1 & 1 & 0.1 & & \\
\hline Betula & 25 & 59.0 & 4 & 2.3 & & & 11 & 2.2 & 40 & 63.5 & & \\
\hline Corylus & 77 & 52.3 & 7 & 1.4 & 4 & 6.3 & 49 & 4.0 & 136 & 66.5 & 4 & 2.8 \\
\hline Quercus & 27 & 27.0 & 7 & 4.4 & 37 & 75.1 & 59 & 19.3 & 136 & 136.6 & 11 & 11.5 \\
\hline Totals & 129 & 138.3 & 18 & 8.1 & 41 & 81.4 & 120 & 25.6 & 313 & 266.7 & 15 & 14.3
\end{tabular}




\subsubsection{Soil micromorphology}

Clare Ellis

\section{Structure 4B: Ring Ditch 008}

Three Kubiena samples $(<397>, 1-3)$ were taken through two fills of Ring Ditch 008 in Structure 4B (Illus 7a). The lower fill (010) is a poorly sorted fine to medium silty sand loam with a few coarse mineral grains and rock fragments. Frequently the mineral grains and rock fragments have thin coatings of silt adhering that is orange in OIL (oblique incident light). This context has been extensively reworked and mixed by worms; more than one phase of bioturbation is evident. Compaction of the faecal pellets has resulted in a vughy microstructure. The relatively high amorphous organic content is burnt, with coarse and silt-sized charcoal occurring throughout the fine organo-mineral matrix. Possible fungal spores are also burnt. There are very few phytoliths. The upper fill (009) is a moderately sorted fine sandy silt with a few coarse mineral grains and rock fragments. There are zones and one band of amorphous and silt-sized charcoal; elsewhere the amorphous organic content is burnt and appears to be largely composed of dissolved charcoal. The very few fungal spores are both burnt and unburnt. There are very few phytoliths. This context has also been extensively mixed by the activities of soil fauna, resulting in the channel microstructure.

Bioturbation, which comprises, at this scale of observation, the activities of soil biota such as earthworms and enchytraeids, has resulted in the destruction of any original soil/sediment fabric and accounts for their open, relatively loose fabrics (Dawod \& FitzPatrick 1992; Davidson 2002: 1248); there is minimal root penetration. Bioturbation has also introduced fine sandy silt loam material which has a much lower charcoal content; this material occurs in the form of veriforms (infilled passages) and granules. There are a few sub-rounded to rounded clasts of iron oxide in both contexts. The iron oxide has oxidised out of solution as infills or impregnations of voids, pores, root pipes etc., but has subsequently been reworked by soil fauna.

The presence of burnt amorphous organic matter, silt-sized charcoal fragments, mineral grains and rock fragments with silt coatings and the low quantities of biogenic silica indicate that the ash derivatives in both contexts were mainly derived from a mineral- based turf. The presence of burnt fungal spores suggests that some decomposition of the organic content had taken place prior to its combustion, as would be expected in a soil. The incomplete combustion of the woody/root component indicates a limited availability of oxygen, due to either the rapid build-up of fuel, or the use of damp fuel, or alternatively due to the deliberate dampening down of the fire, as well as a relatively low-temperature fire such as that found in the domestic hearth (around $400^{\circ} \mathrm{C}$ ) (Courty et al 1989; Simpson et al 2003; Carter 2005). There is no evidence to indicate that the ash was produced in situ. In Upper Fill 009 the dipping band dominated by weathered, bioturbated charcoal shows that the deposits probably accumulated as a series of dumps. This band, rich in charcoal, is likely to be a consequence of incomplete combustion of a woody and/or herbaceous turf fuel, as opposed to a significant change in fuel type (eg Carter 2005). The few coarse fragments of charcoal scattered throughout the matrix are also likely to derive from woody and/or herbaceous organics that were integral to the turfs.

\section{Structure 2B: Ring Ditch 377}

Three Kubiena samples $(<446>1-3)$ were taken through the fills of Ring Ditch 377 in Structure 2B (Illus 10a). The lowermost fill (464) comprises a poorly to moderately sorted fine sandy silt with few rock fragments. It is dominated by burnt amorphous organic matter with frequent to common siltsized charcoal and few clasts of coarse charcoal (roundwood). It contains very few phytoliths, sclerotia and roots. It has been extensively reworked by soil fauna. The upper fill (378) also comprises poorly sorted fine sandy silt dominated by burnt amorphous organic matter, few to frequent charcoal fragments, few burnt and unburnt fungal spores, few phytoliths and very few pieces of highly weathered bone.

The basic micromorphological characteristics of 464 are similar to Area A Structure 2A 006 (upper fill of Pit 005) (Section 10), although 464 contains more silt-sized charcoal. C464 is interpreted as the ashy remnants of a domestic hearth upon which a mixed fuel comprising mineral-based turf, woody and probably herbaceous inclusions were burnt. The boundary between Lower Fill 464 and the overlying Upper Fill 378 is diffuse 
and faint due to post-depositional bioturbation. However, the lower fill is more compact and has a sub-angular blocky microstructure compared to the granular microstructure of the overlying 378; these sedimentary characteristics may be partially due to a hiatus in deposition. Ash of fine organics appears to comprise a high proportion of 378 , and the presence of burnt fungal spores indicates that this too is predominantly a turf ash.

\subsection{Radiocarbon dates}

Twenty-seven dates were returned from this area, all of which were derived from material within the fills of structural components of the roundhouses (Table 5; Illus 18). Given the caveat that taphonomic processes will have influenced the depositional history of the dated material, these features were targeted for dating as it was assumed that this material probably derived from the occupation phase of these structures, and further it was assumed the processes that produced this material, such as cooking and eating, occurred within, or close to, the structure.

The dates indicated activity from the EBA to the MBA, although the majority of dates returned reflect MBA occupation.

Chi-squared $\left(\chi^{2}\right)$ tests were carried out to determine whether the dates within structures were significantly different from each other. From Structure 7B, three of the dates are not significantly different (giving an overall range of 1407-1210 BC), but the fourth (UBA-13422) was. Of the three dates from Structure 5B, UBA-13426 was significantly different from the other two (UBA-13425, UBA-13427), which were not significantly different from each other. Within Structure 2B, each of the paired dates produced significantly different results. However, it should be noted that the date from the upper fill of the ring ditch (UBA-13307, 1387-1133 $\mathrm{BC}$ at $95.4 \%$ probability) had a slightly earlier range than the date from the lower fill (UBA-13308, 1308-1091 BC at $95.4 \%$ probability), indicating that some material may have been redeposited and the dates may be in reverse order of deposition. The four dates from Structure $4 \mathrm{~B}$ were not statistically different. In Structure 6B, the two dates from Post Hole 547 were not statistically significantly different and the other four dates also showed no significant difference from each other, again potentially dating two phases of use. Ignoring UBA-13311 in Structure $3 \mathrm{C}$ as it is clearly anomalous, the other five dates showed no significant differences.

The earlier group of dates from Structures $5 \mathrm{~B}$, $6 \mathrm{~B}, 2 \mathrm{~B}, 7 \mathrm{~B}$ and $4 \mathrm{~B}$ are not significantly different and suggest that these were broadly contemporary. The dates from 3C are also statistically the same as the latest dates in that earlier group. However, as the ring groove of Structure 5B cut the partial ring groove of $7 \mathrm{~B}$, it is unlikely that the two structures were standing at the same time. There is a significant difference between the earliest and latest dates, but the later dates from $2 \mathrm{~B}$ and $6 \mathrm{~B}$ are likely to be contemporary.

There is only so far that analysis of this kind can take the interpretation of factors such as contemporaneity, rebuilding or continuous occupation of individual structures, as there are many taphonomic processes that could result in mixing of deposits or the incorporation of earlier material into contexts, as suggested by the dates from the upper and lower fills of Structure 2B's ring ditch. The above analysis may suggest continuous occupation and rebuilding, but a more cautionary approach would suggest that the dating is more likely to give a general chronology rather than precision at the structural level, due to the spectre of uncertain taphonomy and insufficient temporal resolution.

\subsection{Overview}

\subsubsection{Phasing}

There were very few stratigraphic relationships between features in either Area B or Area C, although spatial and structural relationships do exist.

In Area $B$ there were at least two identifiable phases represented by the earlier Structure 7B which was cut by a feature component of Structure 5B. Structure $7 \mathrm{~B}$ returned two sets of radiocarbon dates; 1391-1216 cal вс (95\% probability; UBA-13423) and 1407-1271 cal в (95\% probability; UBA-13424) from Pit 128 and 1381-1210 cal BC (95\% probability; UBA-13421) and 1431-1316 cal вс (95\% probability; UBA-13422) from Pit 086. The upper and lower date ranges for Structure $5 \mathrm{~B}$ are $1503-1427$ cal BC (95\% probability; UBA-13426) from Post Hole 244 and 1408-1292 


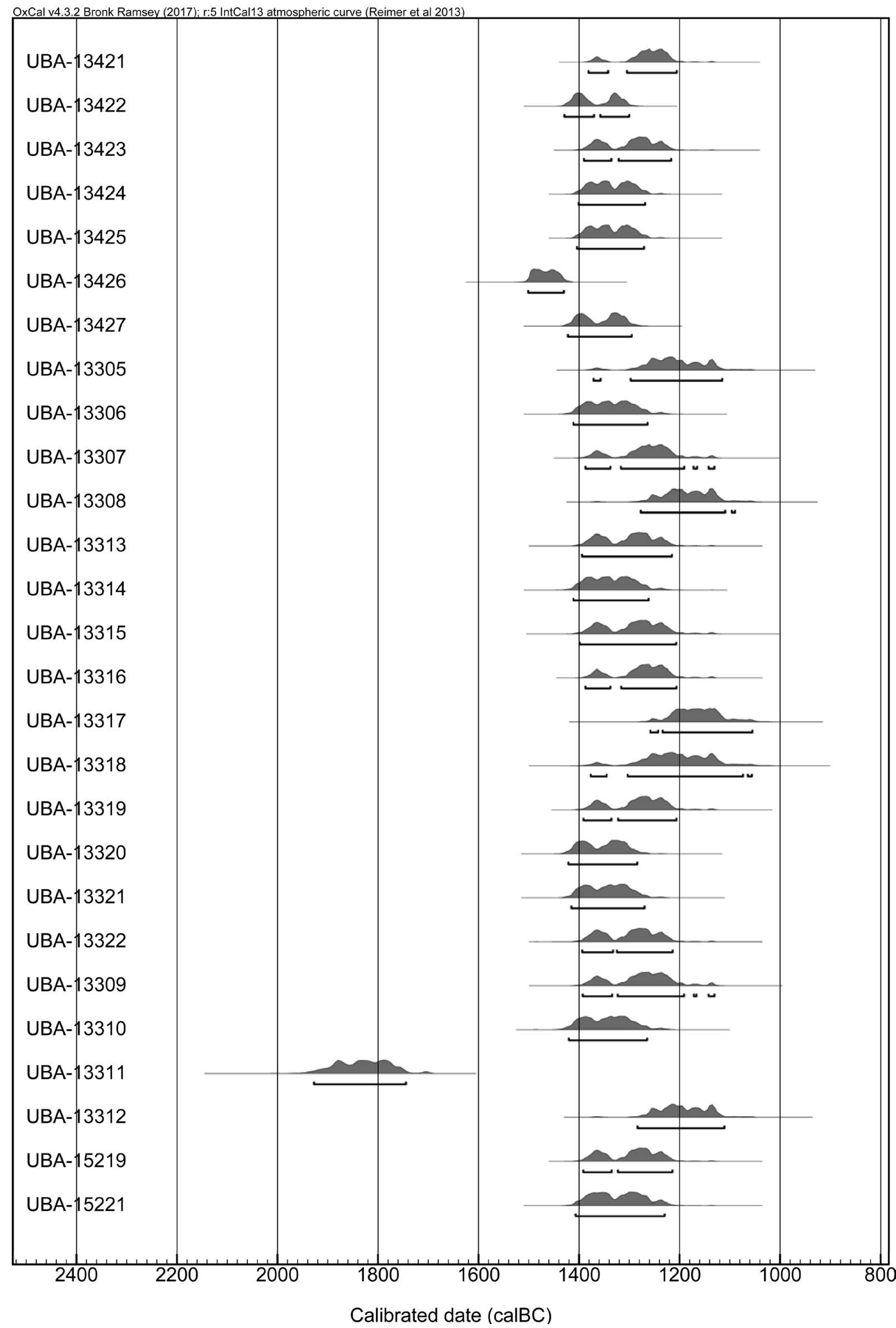

Illus 18 Radiocarbon dates, Areas B and C 
Table 5 Radiocarbon dates, Areas B and C. Calibration was conducted using OxCal v4.1.7, using the IntCal09 calibration curve

\begin{tabular}{|c|c|c|c|c|c|}
\hline Lab no. & Material & Context description & Date вр & $\begin{array}{l}95 \% \\
\text { probability }\end{array}$ & $\begin{array}{l}\delta^{13} \mathrm{C} \\
\% 0\end{array}$ \\
\hline \multicolumn{6}{|l|}{ Structure 7B } \\
\hline UBA-13421 & $\begin{array}{l}\text { Hazel } \\
\text { charcoal }\end{array}$ & Fill of Pit 086 & $3018 \pm 20$ & $1381-1210$ вс & -27.6 \\
\hline UBA-13422 & $\begin{array}{l}\text { Alder } \\
\text { charcoal }\end{array}$ & Fill of Pit 086 & $3106 \pm 20$ & $1431-1316$ вС & -29.7 \\
\hline UBA-13423 & $\begin{array}{l}\text { Hazelnut } \\
\text { shell }\end{array}$ & Fill of Pit 128 & $3036 \pm 24$ & $1391-1216$ вС & -24.7 \\
\hline UBA-13424 & $\begin{array}{l}\text { Hazel } \\
\text { charcoal }\end{array}$ & Fill of Pit 128 & $3066 \pm 19$ & $1407-1271$ вс & \\
\hline \multicolumn{6}{|c|}{ Structure 5B } \\
\hline UBA-13425 & $\begin{array}{l}\text { Willow } \\
\text { charcoal }\end{array}$ & Fill of ?Ring Ditch 150 & $3068 \pm 19$ & $1408-1292$ вс & -27.6 \\
\hline UBA-13426 & $\begin{array}{l}\text { Alder } \\
\text { charcoal }\end{array}$ & Fill of Post Hole 244 & $3197 \pm 19$ & $1503-1427$ вс & -28.5 \\
\hline UBA-13427 & $\begin{array}{l}\text { Hazel } \\
\text { charcoal }\end{array}$ & Fill of Post Hole 151 & $3097 \pm 21$ & $1425-1313$ вс & -25.2 \\
\hline \multicolumn{6}{|l|}{ Structure 2B } \\
\hline UBA-13305 & Barley indet. & Fill of Post Hole 460 & $2986 \pm 30$ & $1370-1123$ вс & -33.4 \\
\hline UBA-13306 & $\begin{array}{l}\text { Hazelnut } \\
\text { shell }\end{array}$ & Fill of Post Hole 460 & $3073 \pm 27$ & $1413-1269$ вс & -26.5 \\
\hline UBA-13307 & Barley indet. & Upper fill of Ring Ditch 377 & $3018 \pm 27$ & $1387-1133$ вс & -25.1 \\
\hline UBA-13308 & Barley indet. & Lower fill of Ring Ditch 377 & $2970 \pm 27$ & $1308-1091$ вс & -23.0 \\
\hline \multicolumn{6}{|l|}{ Structure 4B } \\
\hline UBA-13313 & Barley indet. & $\begin{array}{l}\text { Fill of Pit } 056 \text { in base of Ring } \\
\text { Ditch } 008, \text { underlies } 010\end{array}$ & $3039 \pm 27$ & $1397-1214$ вс & -26.7 \\
\hline UBA-13314 & Barley indet. & $\begin{array}{l}\text { Fill of Pit } 056 \text { in base of Ring } \\
\text { Ditch } 008, \text { underlies } 010\end{array}$ & $3071 \pm 27$ & $1412-1269$ вС & -23.7 \\
\hline UBA-13315 & cf Wheat $s p$ & Fill of Post Hole 102 in post ring & $3033 \pm 30$ & $1400-1210$ вс & -28.5 \\
\hline UBA-13316 & $\begin{array}{l}\text { Barley cf } \\
\text { hulled }\end{array}$ & Fill in Post Hole 098 & $3023 \pm 24$ & $1387-1210$ вС & -24.6 \\
\hline \multicolumn{6}{|l|}{ Structure 6B } \\
\hline UBA-13317 & Barley indet. & Fill of Post Hole 547 & $2955 \pm 26$ & $1266-1056$ вС & -28.9 \\
\hline UBA-13318 & Barley indet. & Fill of Post Hole 547 & $2983 \pm 38$ & $1377-1057$ вС & -32.0 \\
\hline UBA-13319 & Barley indet. & Fill of Post Hole 579 & $3027 \pm 27$ & $1392-1135$ вс & -25.3 \\
\hline UBA-13320 & Barley indet. & Fill of Post Hole 579 & $3093 \pm 26$ & $1428-1303$ вс & -23.7 \\
\hline UBA-13321 & Barley indet. & Fill of Post Hole 543 & $3082 \pm 27$ & $1420-1271$ вс & -26.0 \\
\hline UBA-13322 & Barley indet. & Fill of Post Hole 543 & $3037 \pm 27$ & $1396-1214$ вс & -25.3 \\
\hline
\end{tabular}




\begin{tabular}{|c|c|c|c|c|c|}
\hline Lab no. & Material & Context description & Date вр & $\begin{array}{l}95 \% \\
\text { probability }\end{array}$ & $\begin{array}{l}\delta^{13} \mathrm{C} \\
\% 0\end{array}$ \\
\hline \multicolumn{6}{|l|}{ Structure 3C } \\
\hline UBA-13309 & Barley indet. & $\begin{array}{l}\text { Lower fill of Post Hole } 005 \text { in } \\
\text { post ring }\end{array}$ & $3023 \pm 30$ & $1392-1133$ вс & -30.2 \\
\hline UBA-13310 & Barley indet. & Fill of Post Hole 051 in post ring & $3084 \pm 31$ & $1426-1270$ вс & -30.3 \\
\hline UBA-13311 & Barley indet. & Fill of Pit 071 , cutting Gully 073 & $3511 \pm 34$ & $1925-1745$ вс & -27.6 \\
\hline UBA-13312 & Barley indet. & Basal fill of Post Hole 132 & $2976 \pm 27$ & $1311-1118$ вс & -30.1 \\
\hline UBA-15219 & $\begin{array}{l}\text { Hazel } \\
\text { charcoal }\end{array}$ & Fill of Pit 015 & $3035 \pm 26$ & $1393-1214$ вС & -27.5 \\
\hline UBA-15221 & Barley indet. & Fill of Pit 015 & $3056 \pm 30$ & $1411-1222$ вС & -27.5 \\
\hline
\end{tabular}

cal вс (95\% probability; UBA-13425) from Ring Ditch 150, respectively. These dates may represent two phases of use or alternatively residual material entering the features. Although it can be shown stratigraphically that Structure 7B was the earlier, there is considerable overlap in the date ranges between the two structures, making it difficult to determine a more precise time frame for Structure 7B abandonment. Theoretically, Structure 7B could have been abandoned at any time between $1431 \mathrm{cal}$ BC, the upper range date from Structure $7 \mathrm{~B}$, and $1292 \mathrm{cal} \mathrm{BC}$, the lower date range of Structure 5B.

There was evidence of more than one possible phase in Area C (Illus 12). The curvilinear feature $073 / 114$ was cut by three pits, making this feature stratigraphically earlier. Pit 071, which cuts curvilinear Feature 073, returned a radiocarbon date range of 1925-1745 cal вс (95\% probability; UBA-13311). The pits were interpreted as part of a series forming an arc on the south and south-west of Structure 3C, one of which (132) contained barley grains which returned a date of 1311-1118 cal вс (95\% probability; UBA-13312). The intercutting pits suggest that the gully (073) was abandoned at some point prior to the abandonment of the site itself.

In Area $C$ the short curvilinear feature (106) may be the vestigial remains of a ring groove representing a later or earlier phase than those features assigned to Structure 3C. Alternatively, 106 may be the remains of a drip-gully associated with Structure 3C and therefore of the same phase as that structure. Unfortunately, no dates were obtained for this feature.

It is quite possible that the particular concentration of features around Structure 2B may also represent other undated phases of activity. For instance, it is possible that there exists an arc of pits on the eastern side of the structure that may represent the partial remains of a post ring from another structure, or possibly an encircling fence associated with Structure 2B.

Because Structures 4B, 5B, 2B, 6B and 3C show no stratigraphical relationships with each other, it is impossible to demonstrate whether or not they were contemporary.

\subsubsection{Architectural features of the structures}

The structures in these areas can be classified into three forms: post-built with ring ditches; post-built with ring ditches and ring grooves; and post-built with neither ring ditches nor ring grooves. The lack of apparent phasing within the structures means that it is unclear whether these structural features represent one complete individual structure or several phases of structures at the same location which use slightly different construction methods.

No ring groove was present in either Structure $2 \mathrm{~B}$ or $6 \mathrm{~B}$. There are at least two explanations for the lack of a ring groove. First, the structures were built without a ring groove, the implication being that it was not necessary to set the structures' outer walls within a foundation trench (ring groove). Perhaps the post rings of these structures also functioned as the outer walls. Secondly, the putative ring grooves had been truncated away, which is entirely possible given the shallowness of the surviving ring grooves.

At least three of the structures' entrances (5B, 2B and $6 \mathrm{~B}$ ) were orientated to the south-east and it is 
likely that 3C was similarly orientated. A south-east entrance is a common feature of Bronze Age circular structures across a wide geographical area including Scotland, for example at Kilphedir and Kilearnan Hill, Sutherland (Fairhurst \& Taylor 1971; McIntyre 1998), Bannockburn, Stirling (Rideout 1995), Lairg (McCullagh \& Tipping 1998), Navidale, Helmsdale (Dunbar 2007), Old Meldrum, Aberdeenshire (White \& Richardson 2010) and Drumyocher and Hospital Shields, Aberdeenshire (Johnson 2017). However, recent work by Pope has questioned this south-east dominance in orientation. In her study of circular structures in northern and central Britain she found that the majority of structures in her study $(76 \%)$, where orientation was identifiable, were orientated between the north-east and south, and of these $48 \%$ were orientated between the east and south (Pope 2003: 173). The significance of the entrance orientations is discussed further in Section 11.2.4.

Structure 2B also displayed a wear pattern in the entrance, 490, which intersected with an ill-defined curvilinear feature (394). This feature occupied a space in the inner post ring linking two post holes (399 with 421). Its function is undetermined but may represent some form of threshold construction.

\subsubsection{Finds distribution and taphonomy}

The finds were incorporated into a number of features across each of the structures (Illus 19). The fragmentary nature of the material suggests that much of it was accidentally incorporated. Generally the artefacts were found in the larger features.

The finds within Structure 2B were distributed throughout the structure, but the majority were found within peripheral contexts and may reflect patterns of cleaning, with the central area of the house being swept out and the detritus ending up in what were essentially artefact and sediment traps. However, the majority of the pottery sherds were recovered from the east ring ditch and the external pit (303) to the north of the structure. As Pit 303 was an external feature and was located outside at the rear of the building and not opposite the doorway, it may have been a rubbish pit. Alternatively, Pit 303 may have been the remains of another ring ditch - based on its dimensions and form, $3 \mathrm{~m}$ by $1 \mathrm{~m}$ by $0.16 \mathrm{~m}$ deep, Pit 303 was similar in size and form to the east ring ditch (377) within Structure 2B. Another large external pit (005) just west of Structure 4B also contained pottery sherds. The sherds in both pits derived from more than one vessel, although no complete vessels were recovered, suggesting that the vessels had not broken in situ, the implication being that these pits were not used

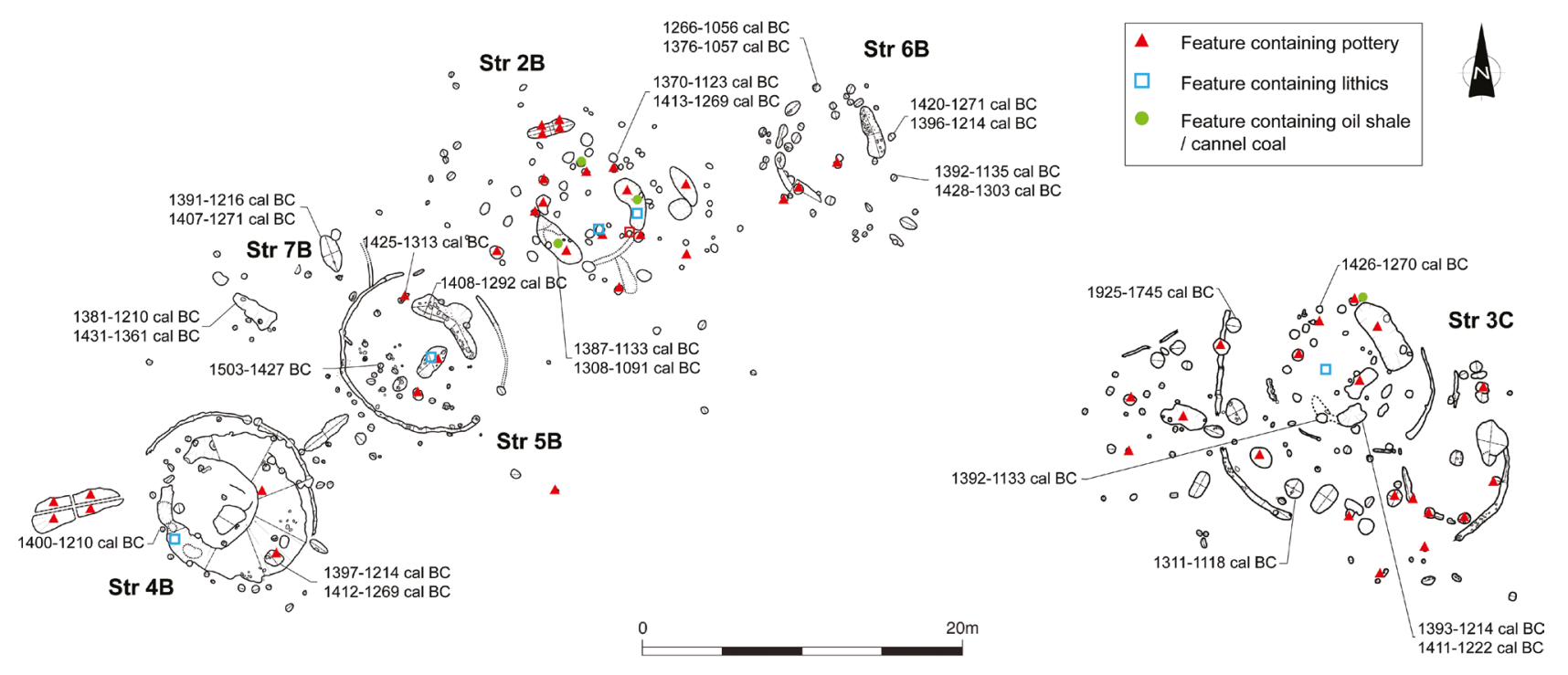

Illus 19 Finds and dating distribution, Areas B and C 
for storage, as one would expect whole artefacts to have been present. It cannot be ruled out, however, that these pits occupied a space in the 'courtyard' of the structures and it was these courtyards that were swept clean. Similarly, pottery was recovered from the fills within an arc of pits that had survived to the south and west of Structure $3 \mathrm{C}$ and may also reflect courtyard cleaning. However, there is increasing evidence of structured deposition at liminal places such as boundaries and this arc of pits with their deposits of pottery may have served as a metaphorical or symbolic boundary (Brück 2001).

\subsubsection{Structure use}

It is likely that all these structures were primarily houses, but they may also have served other functions such as animal byres and workshops.

There is evidence for craft specialisation represented by the production of jewellery. The finds from Structure 2B included a fragmented cannel coal 'napkin ring' which was recovered from the ring ditch (417), and unworked tabular oil shale from the eastern ring ditch (377) and Post Hole 467. Other material remains from Structure 2B, including flint tools, pottery and a large used anvil stone, are indicative of working and production, as are the weights fashioned from coarse stone, found in contexts associated with Structure 3C.
Features common to the majority of the structures within Areas B and C were internal ring ditches. There is much debate regarding the purpose of ring ditches, and this is reviewed in Section 11.2.2.

\subsubsection{Economy}

The cereal grain assemblage recovered from Areas $\mathrm{B}$ and $\mathrm{C}$ was dominated by barley, associated with weed seeds that were typical of arable fields, indicating that arable farming was being practised. Unfortunately, the species represented by the few fragments of calcined bone could not be determined, so it is uncertain whether these animals were domesticated or wild.

The evidence for craft specialisation in Structure $2 \mathrm{~B}$ hints at possible manufacture of tradable commodities but unfortunately, it is impossible to determine whether the jewellery was produced in this structure, if it was meant for personal consumption or trade, or whether those who manufactured the jewellery collected the raw materials.

Two probable stone weights from Area C were recovered during pre-excavation cleaning of Structure 3C, and a third unfinished weight was recovered from curvilinear Feature 073. It is possible that the objects were related to weaving, which may have taken place in this structure, possibly indicating some specialisation of function. 